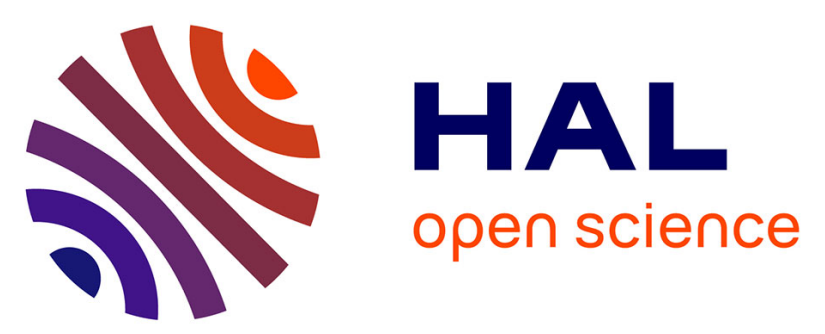

\title{
Perfluoroalkyl substances (PFAS) in fish from European lakes: current contamination status, sources, and perspectives for monitoring
}

Sara Valsecchi, Marc Babut, Michela Mazzoni, Simona Pascariello, Claudia Ferrario, Beatrice de Felice, Roberta Bettinetti, Bruno Veyrand, Philippe Marchand, Stefano Polesello

\section{To cite this version:}

Sara Valsecchi, Marc Babut, Michela Mazzoni, Simona Pascariello, Claudia Ferrario, et al.. Perfluoroalkyl substances (PFAS) in fish from European lakes: current contamination status, sources, and perspectives for monitoring. Environmental Toxicology and Chemistry, 2021, 40 (3), pp.658-676. 10.1002/etc.4815 . hal-03153331

\section{HAL Id: hal-03153331 \\ https://hal.science/hal-03153331}

Submitted on 26 Feb 2021

HAL is a multi-disciplinary open access archive for the deposit and dissemination of scientific research documents, whether they are published or not. The documents may come from teaching and research institutions in France or abroad, or from public or private research centers.
L'archive ouverte pluridisciplinaire HAL, est destinée au dépôt et à la diffusion de documents scientifiques de niveau recherche, publiés ou non, émanant des établissements d'enseignement et de recherche français ou étrangers, des laboratoires publics ou privés. 


\title{
Perfluoroalkyl substances (PFAS) in fish from European lakes: current contamination status, sources, and perspectives for monitoring.
}

Sara Valsecchi ${ }^{\mathrm{a} 1}$, Marc Babut ${ }^{\mathrm{b} 1}$, Michela Mazzoni ${ }^{\mathrm{a}, \mathrm{c}}$, Simona Pascariello $^{\mathrm{a}}$, Claudia Ferrario ${ }^{\mathrm{a}}$, Beatrice De Felice $^{\mathrm{d}}$, Roberta Bettinettic ${ }^{\mathrm{c}}$, Bruno Veyrand ${ }^{\mathrm{e}}$, Philippe Marchand ${ }^{\mathrm{e}}$, Stefano Polesello ${ }^{\mathrm{a}}$

${ }^{a}$ IRSA-CNR, Water Research Institute, National Research Council of Italy, Brugherio, Italy

${ }^{\mathrm{b}}$ INRAE- RIVERLY, Interdisciplinary research unit for the management and restoration of river systems and their catchments, French National Research Institute for Agriculture, Food and Environment, Villeurbanne, France

${ }^{c}$ Department of Human Sciences and Innovation for the Territory, University of Insubria, Como, Italy

${ }^{\mathrm{d}}$ Department of Environmental Science and Policy, University of Milan, Milano, Italy

${ }^{\mathrm{e}}$ LABERCA, Oniris, INRA - The Laboratory for the Study of Residues and Contaminants in Foods, National veterinary school, Université Bretagne Loire, Nantes, France

${ }^{1}$ These authors contributed equally to this work: Sara Valsecchi valsecchirsa.cnr.it; Marc Babut marc.babut@inrae.fr

\begin{abstract}
Fish concentrations of perfluorocarboxylic and perfluorosulfonic acids were reported for seven deep lakes in the European subalpine area, namely Lake Geneva, L. Lugano and L. Maggiore, L. Iseo, L. Como, L. Garda and L. Mergozzo, one shallow lowland (L. Varese) and two high-altitude alpine (> $2000 \mathrm{~m}$ asl) lakes. Fillets and, in selected cases, other body fractions (viscera, liver and residual carcass) from eight fish species were analysed. The possibility of harmonizing the monitoring protocols was tested: the results suggest that the sampling season is not critical for PFASs and the total protein content cannot be used for normalization of tissue concentrations because PFASs bind to specific proteins. Moreover, the polar lipid content could be used to reduce the variability of PFAS concentrations in phospholipid rich fractions of fish such as viscera and carcass. The data comparison and analysis demonstrate that the PFAS contamination in lake fish is generally correlated with the degree of the urbanization of the lake catchment, but it is sometimes difficult to compare absolute concentrations in lake fish, because the lake hydro-morphological characteristics have a substantial role in determining the chemical concentrations of persistent and mobile contaminants.
\end{abstract}

Keywords: Perfluoroalkyl substances, bioaccumulation, persistent compounds, lakes, freshwater fish, biota monitoring, 


\section{INTRODUCTION}

Within continental waters, large lakes present special features because of their physical characteristics, especially a long residence time, and the services they can provide to human populations. The South-western part of the Alps in Europe holds several of these large lakes, among the largest in Europe. These lakes are the main source of drinking waters for residential population, and they also sustain recreational as well as economic activities such as professional fishing, tourism and shipyards. Nevertheless, they suffer from significant anthropic pressures, because they are surrounded by densely populated areas, industries and extensive agriculture.

Monitoring persistent contaminants in fish is therefore an essential component of environmental and health risk assessment in such large lakes. Institutional monitoring programs of legacy contaminants have been running for many years especially in the transboundary lake basins in this region such as Lake Geneva (CIPEL) and Lake Maggiore with Lake Lugano (CIPAIS).

Perfluoroalkyl and polyfluoroalkyl substances (PFASs) are a wide class of persistent chemicals, which has attracted attention in the last two decades, because of their unique properties, widespread uses in consumer products and presence in various environmental compartments (Houde 2006; Ahrens 2011a; Houde 2011; Gewurtz 2013). Among PFASs, perfluoroalkyl sulfonates (PFSAs) such as PFOS (perfluorooctane sulfonate) and many perfluoroalkyl carboxylic acids (PFCAs) have been shown to be bioaccumulative (Kannan 2005; Houde 2006; Houde 2011) or toxic to humans and other species (Beach 2006; Lau 2007). PFOS was listed on Annex B of the Stockholm Convention in 2009 (UNEP-POPS 2009). Consequently, the States that signed the Stockholm convention must monitor PFOS in their environment; therefore the European Union added PFOS to the list of priority pollutants to be monitored in continental water in 2013 (2013/39/EU 2013). Perfluorooctanoate (PFOA) was listed on the Annex A of the Stockholm Convention in 2019 (UNEP-POPS 2019) and perfluorohexane sulfonate (PFHxS) has been proposed for listing under Stockholm Convention and is currently under review (UNEP-POPS 2017).

The aim of the present work is to review the status of PFAS contamination in fish from lakes from the Alpine area, comparing large deep lakes and smaller shallow ones belonging to the same catchments, which include also two high altitude reference lakes. Data gathered from different monitoring programs, carried out by local authorities for each lake, allowed a wide assessment of PFAS contamination in fish across the South-western subalpine area for the last five years (20152019). The collected dataset gave us the opportunity to highlight PFAS sources and transport 
mechanism in this area as well as to discuss some technical aspects of PFAS monitoring in fish, with a specific focus on EU regulation for biota monitoring in European freshwaters. .

\section{MATERIAL AND METHODS}

Study area

Ten European glacial lakes in pre-alpine and alpine areas were investigated in this study (Fig. 1). These lakes were chosen to cover similar aquatic environments with a gradient of anthropogenic pressures: from remote to densely populated and industrialised areas.

Lake Geneva, Lake Lugano and Lake Maggiore are transboundary subalpine lakes between France and Switzerland or between Italy and Switzerland. Five lakes (Lakes Como, Iseo, Garda, Varese and Mergozzo) are entirely on Italian territory on the southern side of the Alps. The two high altitude alpine lakes (Lake Sassolo upper and Lake Sassolo lower) are interconnected and located in Switzerland.

Lake Geneva, in the Rhône river basin, is a deep lake on the western side of the Alps and is one of the largest lakes in Western Europe. The lakes Maggiore, Como, Iseo and Garda are deep glacial lakes that form the subalpine Italian lacustrine district belonging to the Po river basin and constitute about $70 \%$ of all Italian freshwater resources. Lakes Lugano, Varese and Mergozzo belong to the Lake Maggiore hydrological catchment: their outlet rivers (the river Tresa, the river Bardello and an artificial canal respectively) directly flow into the Lake Maggiore. Lake Mergozzo is a small and deep lake located in a less urbanised and protected area (Mazzoni 2020) whereas Lake Varese is a shallow, medium size lake sited in a densely populated and industrialised territory.

Lake Sassolo upper and Lake Sassolo lower are located in Maggia Valley (Canton Ticino, CH) which is a tributary of the Lake Maggiore. They have been chosen as monitoring sites of the International Cooperative Programme on Assessment and Monitoring Effects of Air Pollution on Rivers and Lakes (ICP Waters) because they are located at altitude more than $2000 \mathrm{~m}$ a.s.1 but in a region highly affected by long-range transport of atmospheric pollutants (Steingruber 2018).

The main geographical, chemical and physical characteristics of the lakes are reported in Table S1 (in Supplemental Materials).

Fig 1. Study area with the sampled Lakes. Left picture was downloaded from Eurostat (2014). 
Study species

Eight fish species were collected: shad (Alosa agone), European whitefish (Coregonus lavaretus), burbot (Lota lota), rainbow trout (Oncorhynchus mykiss), European perch (Perca fluviatilis), roach (Rutilus rutilus), brown trout (Salmo trutta) and Arctic char (Salvelinus alpinus).

These species have different habitats, feeding behaviours and spawning time. For example, shad is a pelagic non-migratory species, mainly zooplanktivorous, and its spawning period ranges from June to August (Kottelat 2007), while burbot usually lives in deep waters, feeds on benthic invertebrates and reproduces between November and March. Roach feeds on zooplankton, algae or plants and detritus (Horppila 1997; Kamjunke 2002), while perch is considered an opportunistic diurnal predator, living in the littoral zone. In Table S2 the main biological and ecological characteristics of all sampled species are reported.

\section{Sample collection and preparation}

The choice of fish species for the present study depended on their abundance in the study area as well as their catching in as many lakes as possible. Fish specimens were caught by professional fishermen. Most of the fish had reached their sexual maturity. Lake Geneva fish were collected throughout the lake during the summer 2018, outside the reproductive period. Fish of the other lakes were collected from 2015 to 2019 in different seasons. Fish from both Lakes Sassolo were sampled during the 2018 monitoring campaign in the framework of ICP Waters activities (Steingruber 2018). Fish from Lake Lugano were sampled in the framework of the monitoring programmes of the International Commission for the Protection of Italian-Swiss Water (CIPAIS) (Solcà 2016, 2019). Generally, two species of fish were collected per lake with the exception of lakes Como and Garda, where only shad was caught. In Lake Maggiore three species were sampled (shad, European whitefish and roach) while in Lake Mergozzo six fish species were collected (shad, European whitefish, burbot, European perch, roach and Arctic char). Shad is the fish species caught in most lakes (Lake Mergozzo, L. Maggiore, L. Lugano, L. Como, L. Iseo and L. Garda). Fish were measured and weighted. The Table S3 summarises sampling information and fish characteristics.

Fish from Lake Geneva were stored refrigerated (approximately $4^{\circ} \mathrm{C}$ ) until they could be frozen ($20^{\circ} \mathrm{C}$ ), and then sent to LABERCA (French Reference Laboratory for halogenated pollutants in food) for further treatment and analysis. Fish specimens from the other lakes arrived within few hours after collection at the Water Research Institute laboratory for further treatments and analysis.

Sample treatment 
The fish dorsal muscle (i.e. the fillet) from all specimens was separated from the skin (EC 2006). Some fish specimens were dissected into three or four fractions: muscle (separated from the skin), whole viscera (which include the liver) or entrails and liver separately, and carcass (consisting of all the rest of the fish, i.e. head, fishbone, skin and fins). The weights of each fraction (i.e. muscle (F), viscera (V) or entrails (E) and liver (L) and carcass (C)) in each sample are reported in Table S3.

Muscle and viscera samples from Italian lakes, consisting in single or pooled samples up to 21 specimens (Table S3), were homogenized in 15-ml PE vials by Ultra-Turrax T25 (Janke \& Kunnel, IKA®-Labortechnik), whereas the carcass samples were frozen at $-21^{\circ} \mathrm{C}$ and crumbled with an ice crusher before the extraction. Dry weight was determined after drying an aliquot (from 2 to $3 \mathrm{~g}$ wet weight - ww) of fish fractions at $105^{\circ} \mathrm{C}$ overnight. Lipid content $\left(f_{\text {Lip }}\right)$ was measured by cyclohexane/isopropanol extraction standard method developed by Smedes (1999) for marine biota monitoring programs. Protein content evaluation $\left(f_{\mathrm{Pr}}\right)$, polar lipids $\left(f_{\mathrm{LP}}\right)$ and neutral lipids $\left(\mathrm{f}_{\mathrm{LN}}\right)$ determination were conducted on selected fish according to Bradford (1976) and to Palacios (2005) as described in Supplemental Material.

Fish specimens from Lake Geneva were defrosted and dissected into four fractions, namely fillets, liver, entrails (viscera without liver) and carcass. However, in some cases liver and entrails were pooled, so as to get a sufficient mass for analysis. Fractions were further freeze-dried and finely ground, to get a homogenous powder. Dry weight was determined on whole samples subjected to freeze-drying.

\section{PFAS chemical analysis}

In the case of Italian samples, fish tissues were analysed for the determination of nine perfluorocarboxylic acids, namely perfluorohexanoate (PFHxA), perfluoroheptanoate (PFHpA), PFOA, perfluorononanoate (PFNA), perfluorodecanoate (PFDA), perfluoroundecanoate (PFUnDA), perfluorododecanoate (PFDoDA), perfluorotridecanoate (PFTrDA), perfluorotetradecanoate (PFTeDA) and two perfluoroalkyl sulfonates, namely PFHxS and PFOS. A full list of chemicals, solvents and standards is provided in the Supplemental Material (Table S4). The extraction and the analysis by liquid chromatography tandem mass spectrometry were carried out according to Mazzoni (2016) and described in Supplemental Material (section III).

For Lake Geneva fish, the analytical method was developed to determine the concentration of five perfluoroalkyl sulfonates (perfluorobutane sulfonate (PFBS), PFHxS, perfluoroheptane sulfonate (PFHpS), PFOS and perfluorodecane sulfonate (PFDS)) and nine perfluorocarboxylic acids (perfluorobutanoate (PFBA), perfluoropentanoate (PFPeA), PFHxA, PFHpA, PFOA, PFNA, PFDA, PFUnDA, PFDoDA) (Riviere 2014). Details are provided in Supplemental Material (section III). 
$Q A / Q C$-In the Water Research Institute laboratory, limits of Detection (LODs) and limits of Quantification (LOQs) in fish tissue were estimated, according to ISO Standard 6107-2: 2006, as respectively, three-fold and tenfold the standard deviation of an extract of biological tissue fortified at $1 \mu \mathrm{g} / \mathrm{L}$. LOD and LOQ values ranged from 0.01 to 0.13 and from 0.02 to $0.33 \mathrm{ng} / \mathrm{g}$ ww respectively (Table S5). A procedural blank was run every extraction batch: PFAS concentrations were always below respective LODs. Method trueness was assessed by the analysis of IRMM-427, a reference fish fillet certified for the mass fraction of perfluoroalkyl substances (Dabrio Ramos 2015).

In LABERCA, QA/QC procedures included the use of appropriate internal standards in each sample, while labelled external standards were systematically added at the end of each analytical batch, in order to determine recoveries. Further, a continuous monitoring of the analytical procedure was implemented through procedural blanks, in order to check for the absence of external contamination. Reproducibility was assessed using a quality control sample (QC) regularly characterized over several years. LODs and LOQs were determined similarly to the Water Research Institute process, and were into the range 0.01 to $0.10 \mathrm{ng} / \mathrm{g}$ ww, except for short chain perfluorinated alkyl acids (PFBA and PFPA) for which the sensitivity was lower.

Both laboratories participated to the IMEP-42 round-robin study, which used the abovementioned IRMM-427 certified sample. The performance of participating laboratories was assessed by calculating Z-scores according to ISO/IEC17043 (Dehouck 2015). Z-scores of both methods were satisfactory, because their absolute values were close to 1 , ranging from -0.52 to +0.82 for the Water Research Institute, and from -0.77 to +1.15 for LABERCA for all the six compounds (PFHxS, PFOS, PFNA, PFDA, PFUnDA, PFDoDA) reported by the CRM provider (Dabrio Ramos 2015).

\section{Data processing}

Viscera concentrations - In cases where entrails and liver were analysed separately, PFAS concentrations in whole viscera $(\mathrm{V})$ were determined as the weighted mean of concentrations in fractions according to equation (1):

Conc $_{V}=\frac{\left(\text { Conc }_{E} \times \text { weight }_{E}\right)+\left(\text { Conc }_{L} \times \text { weight }_{L}\right)}{\text { weight }_{E}+\text { weight }_{L}}$

Equation (1)

where the subscript $E$ means entrails and the subscript $L$ corresponds to liver.

Whole-body concentrations-Whole-body (WB) PFAS concentrations were determined as the weighted means of concentrations in fractions according to equation (2):

Conc $_{W B}=\frac{\left(\text { Conc }_{F} \times \text { weight }_{F}\right)+\left(\text { Conc }_{V} \times \text { weight }_{V}\right)+\left(\text { Conc }_{C} \times \text { weight }_{C}\right)}{\text { weight }_{F}+\text { weight }_{V}+\text { weight }_{C}} \quad$ Equation (2) 
Where $F$ means fillet, $C$ corresponds to carcass and $V$ to viscera, incl. liver. In the same way the whole-body dry weight, fresh weight, lipid content, polar lipids and protein contents were calculated. Dry weight fraction $\left(f_{d w}=g_{d w} / g_{w w}\right)$ was determined in most fillet samples and also in viscera and carcass of the dissected fish.

Degree of Urbanization Index-For the catchments of the largest lakes, we applied the Degree of urbanization (DEGURBA) classification developed by EUROSTAT as a proxy for the anthropic pressure (Eurostat 2020a). Based on the share of local population living in urban clusters and in urban centers, this index classifies local administrative units into three categories: 1) Class 1: urban centers (densely populated areas); 2) Class 2: urban clusters (intermediate density areas); 3) Class 3: Rural areas (thinly populated areas). Because urban clusters (Class 2) are defined with a population density of at least 300 inhabitants per $\mathrm{km}^{2}$ while urban centers (Class 1) with a population density of at least 1500 inhabitants per $\mathrm{km}^{2}$ (i.e. five times the Class 2 density), we defined a Degree of Urbanization Index (DUI) as:

$$
\begin{array}{ll}
\text { DUI }=5 *(\% \text { Class } 1)+(\% \text { Class } 2) & \text { Equation }(3)
\end{array}
$$

The Degurba data for the catchments of the largest lakes and their calculated DUIs are shown in Table S6.

Statistics - Distributions of fish concentrations accounting for non-detects were obtained with ProUCL 5.1 (USEPA 2016). For datasets with more than $50 \%$ of censored data (i.e. less than $50 \%$ of data above the detection limits), only median and concentration ranges were reported.

Shapiro-Wilk tests were carried out in order to check for normality within groups. Unpaired twosample t-test, following a $F$-test for variance homogeneity, was used to evaluate significant differences between two normal distributed and homogeneous sets of data. Wilcoxon rank sum test was applied to evaluate significant differences between two non-normal distributed sets of data. ANOVA (for normally distributed data) or Kruskal-Wallis (in the case of non-normal distributed data) tests were used for variance analysis. Kruskal-Wallis test was followed by Dunn post-hoc test in the case of significant differences.

The correlations between fillet and whole-body concentrations were assessed by Theil-Sen regression, to include censored data in the datasets, after having carried out a trend analysis by the Mann-Kendall test. We also applied the analysis of covariance (ANCOVA) in order to compare the slopes of regressions between fillet and whole-body concentrations, when the detection rates equaled $100 \%$.

Significance was set at $\alpha=0.05$ in all tests. 


\section{RESULTS}

\section{Characterization of fish}

The biometric data of fish and their fractions are reported in Table S7 in Supplemental Material. The weight percentage of the three fractions (fillet, viscera and carcass) was determined in the four dissected species (shad, burbot, roach and brown trout) (Table S7). Viscera was the smallest fraction which constituted from 9 to $14 \%$ of the fresh whole-body (WB) weight. Carcass was the largest fraction (47-55\%), whereas fillet represented from 32 to $41 \%$ of the fresh WB weight. Dry weight fraction of WB $\left(\mathrm{f}_{\mathrm{dw}}\right)$ was calculated according to equation (2) and ranged from 0.22 to $0.32\left(\mathrm{~g}_{\mathrm{dw}} / \mathrm{g}_{\mathrm{ww}}\right)$. Lipid content ( $f_{\text {Lip }}$ ) was determined in most fillets and also in the dissected viscera and carcass samples. Shad had the highest lipid content ( $\left.f_{L i p}\right)$ in fillets. Analysis of protein $\left(f_{P r}\right)$, polar lipids ( $\left.f_{L P}\right)$ and neutral lipids $\left(f_{\mathrm{LN}}\right)$ content was carried out only for three different fractions of trout and shad. Protein content, ranging from $0.07 \pm 0.02$ to $0.08 \pm 0.02$, was the same in the three fractions. The highest content of polar lipids was observed in viscera $(0.41 \pm 0.13)$ while the highest content of neutral lipids was detected in the carcass fractions $(0.11 \pm 0.02)$.

PFAS levels in fish

The dataset presents PFAS contamination in fish in the subalpine area during the last five-year period. Aggregated data are summarized in Tables 1-3, which are divided according to lakes and matrices, while the complete dataset is available as Supplemental material (Tables S8-S11).

PFTrDA and PFTeDA were not determined in Lake Geneva, Lake Mergozzo and Lake Lugano on 2015. PFBA, PFPeA, PFBS, PFHpS and PFDS were measured only in Lake Geneva, but, being always below the LODs (respectively $0.2 ; 0.2 ; 0.02 ; 0.02 ; 0.02 \mathrm{ng} \mathrm{g}^{-1} \mathrm{ww}$ ), they were not further discussed nor included in the tables.

Taking into consideration the whole fillet dataset, which it is the most comparable one, the most frequently found compounds were PFOS and PFDoDA (100\% of detection) followed by PFDA and PFUnDA (92-98\%). The highest concentrations were measured for PFOS (from 0.2 to $50.5 \mathrm{ng} / \mathrm{g} \mathrm{ww}$, median $6.0 \mathrm{ng} / \mathrm{g} \mathrm{ww}$ ) followed by PFDA ( $<\mathrm{LOD}$ to $12.0 \mathrm{ng} / \mathrm{g} \mathrm{ww}$; median $0.5 \mathrm{ng} / \mathrm{g} \mathrm{ww}$ ), PFUnDA (<LOD to $8.9 \mathrm{ng} / \mathrm{g} \mathrm{ww}$; median $0.3 \mathrm{ng} / \mathrm{g} \mathrm{ww}$ ), and PFDoDA (0.01 to $4.81 \mathrm{ng} / \mathrm{g} \mathrm{ww}$; median $0.3 \mathrm{ng} / \mathrm{g}$ Ww).

Similar concentration results were obtained for carcass and viscera, where long chain PFCAs (from $\mathrm{C} 10$ to $\mathrm{C} 14)$ and PFOS were detected in more than $95 \%$ of the samples. The highest concentrations were measured for PFOS (viscera: from 3.6 to $77.0 \mathrm{ng} / \mathrm{g}$ ww, median $25.9 \mathrm{ng} / \mathrm{g}$ ww; carcass: from 
2.1 to $55.2 \mathrm{ng} / \mathrm{g} \mathrm{ww}$, median $14.8 \mathrm{ng} / \mathrm{g} \mathrm{ww}$ ) and PFDA (viscera: from 0.6 to $7.0 \mathrm{ng} / \mathrm{g} \mathrm{ww}$, median 2.1 ng/g ww; carcass: from <LOD to $3.5 \mathrm{ng} / \mathrm{g} \mathrm{ww}$, median $1.2 \mathrm{ng} / \mathrm{g} \mathrm{ww})$.

From PFNA (9 carbon atoms) to PFHxA (6 C), the frequency of detection significantly decreased from $48 \%$ to $9 \%$ in fillet samples and from about $80 \%$ to $10-20 \%$ for the other examined matrices (Tables 1-3), following the well-known decrease of the bioaccumulation potential as a function of the decrease in perfluorinated chain length (Martin 2003a; Martin 2003b; Zhao 2013).

For the investigation of the possible influence of seasonality on PFAS concentrations in fish, data from four lakes (Lake Como, Lake Garda, Lake Lugano and Lake Maggiore), which were sampled in the four seasons of 2018, were pooled according to the season. Shads were sampled in all the lakes in every season, whereas European perches were seasonally caught only in Lake Lugano. No statistical differences were observed among the seasons for all the compounds (Kruskal-Wallis: $p>0.5$ ) regardless of whether two species were considered (shad and European perch) or only one (shad) (Fig. S1).

The difference among species could be carried out only in Lake Lugano, Lake Varese and Lake Geneva where at least three specimens for each different species were available (roach and burbot in Lake Geneva, shad and European perch in Lake Lugano and European perch and roach in Lake Varese). Statistical analysis, carried out between the couples of species, showed no significant differences $(p>0.05)$ for PFOS and long chain PFCAs in fillets (Fig. S2). It was not possible to carry out the same comparison for viscera samples due to the paucity of data.

\section{PFAS pattern of contamination in lakes}

One of the aims of the present work was to assess the status of fish contamination by PFASs in the European subalpine lakes in the Alpine area. In this section we focused mainly on fillet data, because the largest dataset is available for this matrix, allowing to compare fish concentrations among lakes. The dataset covers a wide concentration range, from high altitude and remote lakes (e.g. PFOS: from 0.2 to $0.8 \mathrm{ng} / \mathrm{g} \mathrm{ww}$, median 0.3 in lakes Sassolo) to low altitude and highly populated ones (e.g. PFOS: from 3.7 to $50.5 \mathrm{ng} / \mathrm{g} \mathrm{ww}$, median 15.7 in Lake Lugano).

Even if monitoring programs were not designed for the compliance checking with the EU Environmental Quality Standards for biota $\left(\mathrm{EQS}_{\text {biota }}\right)$, derived from the WFD regulation, we could get a rough assessment of each lake status, by comparing geometric means of the whole dataset,

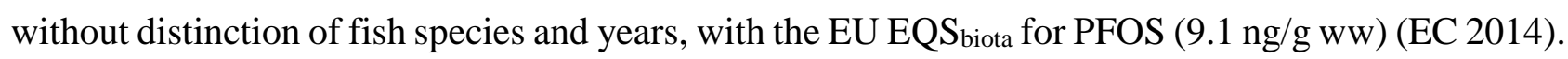
Geometric means of PFOS concentrations in Lakes Iseo, Garda, Como, Mergozzo and Varese (1.0, 1.4 and 3.5, 4.5 and $5.7 \mathrm{ng} / \mathrm{g}$ ww respectively) were lower than the EU EQS ${ }_{\text {biota }}$ for PFOS. On the 
contrary, geometric means of Lakes Maggiore and Geneva (8.4 and $8.9 \mathrm{ng} / \mathrm{g}$ ww respectively) were close to this standard, which was widely exceeded in Lake Lugano (PFOS geometric mean:16.0 ng/g ww). (Fig. 2).

As regards the sum of long chain PFCAs (Table S12), lake Lugano showed the highest values (median $4.2 \mathrm{ng} / \mathrm{ww}$, but with a wide variability, from 0.7 to $16.8 \mathrm{ng} / \mathrm{g} \mathrm{ww}$ ), followed by Lakes Varese, Mergozzo and Geneva (medians 3.3, 3.1 and $2.2 \mathrm{ng} / \mathrm{g}$ ww, respectively). On the contrary, long-chain PFCA concentrations in Lakes Maggiore, Como, Iseo and Garda (medians from 0.36 to $0.64 \mathrm{ng} / \mathrm{g}$ ww) were of the same order of magnitude as those determined in high altitude Sassolo lakes (median $0.44 \mathrm{ng} / \mathrm{g} \mathrm{ww})$.

Of the PFAS measured in all low altitude lakes, PFOS represented more than 50\%, ranging from $62 \%$ in Lake Iseo to $88 \%$ in Lake Maggiore (Fig. 3). In the high altitude lakes, C10-C14 PFCAs represented about $65 \%$ of the total PFASs. PFDA made up $25 \%$ of $\Sigma$ PFAS in Lake Varese, far above the proportion observed in all other investigated lakes. Similarly, PFUnDA was present in a significant proportion (13\%) of $\Sigma$ PFAS in Lake Mergozzo while PFHxS (2.5\%) in Lake Geneva, which were both higher than in all other lakes. These observations suggest specific, but not yet identified, PFAS sources in these lakes. It is interesting to note that PFOA has been detected only in six lakes but with a very limited percentage contribution: the maximum PFOA percentage (1.5\%) was measured in Lake Iseo, confirming that PFOA has a limited accumulation in biota.

For two lakes, Como and Lugano, their morphology allows to distinguish two distinct areas. Lake Como is divided into two branches named Como and Lecco, while in the case of Lake Lugano the Melide dam divides the north and south parts. In both cases, the differences in concentrations and patterns were not significant, showing that the site of catching was not critical regarding the collected fish species, which included both pelagic and demersal ones. 

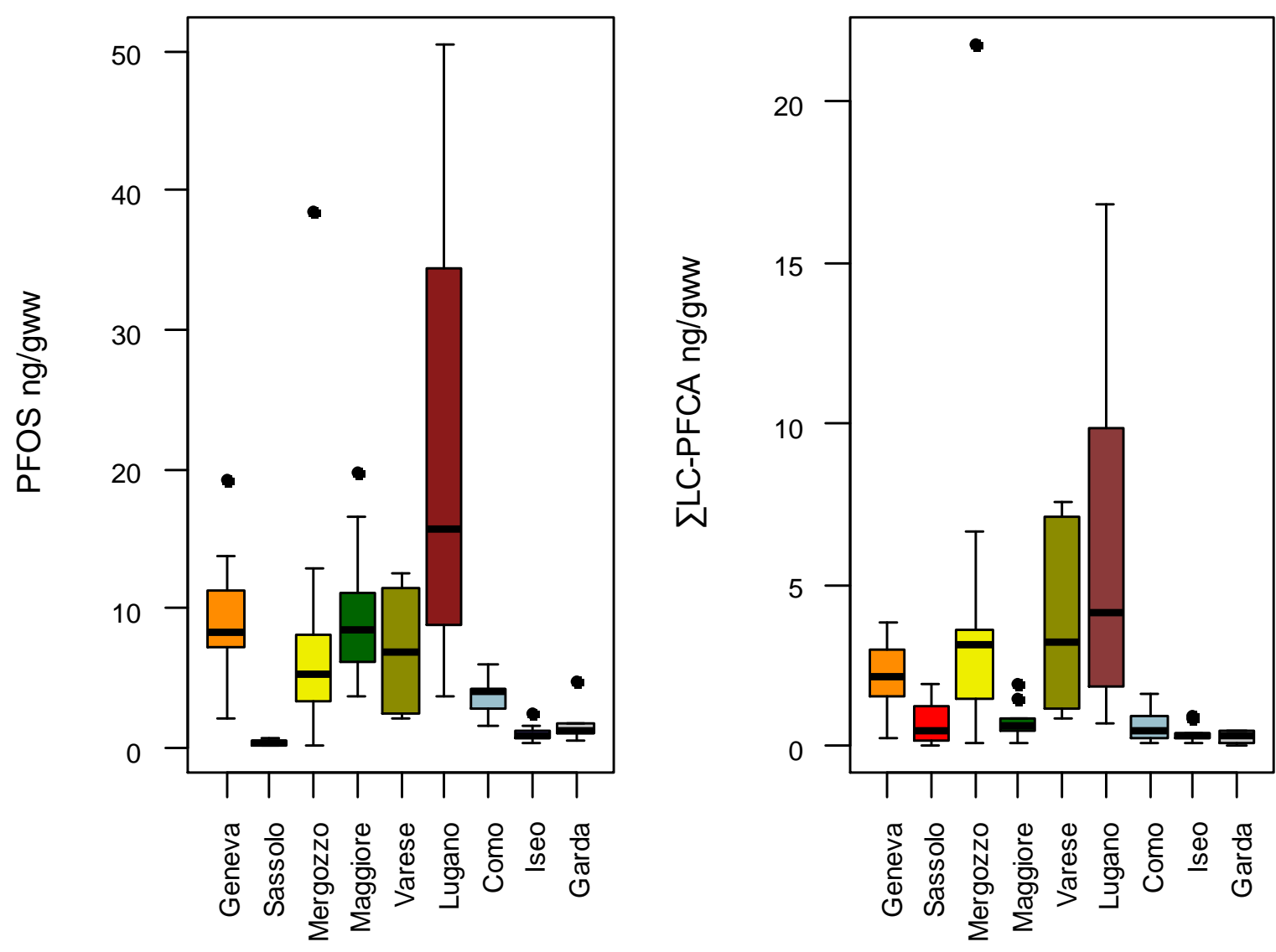

Fig. 2 Box-whisker plot of the fillet PFAS concentrations in the different lakes 


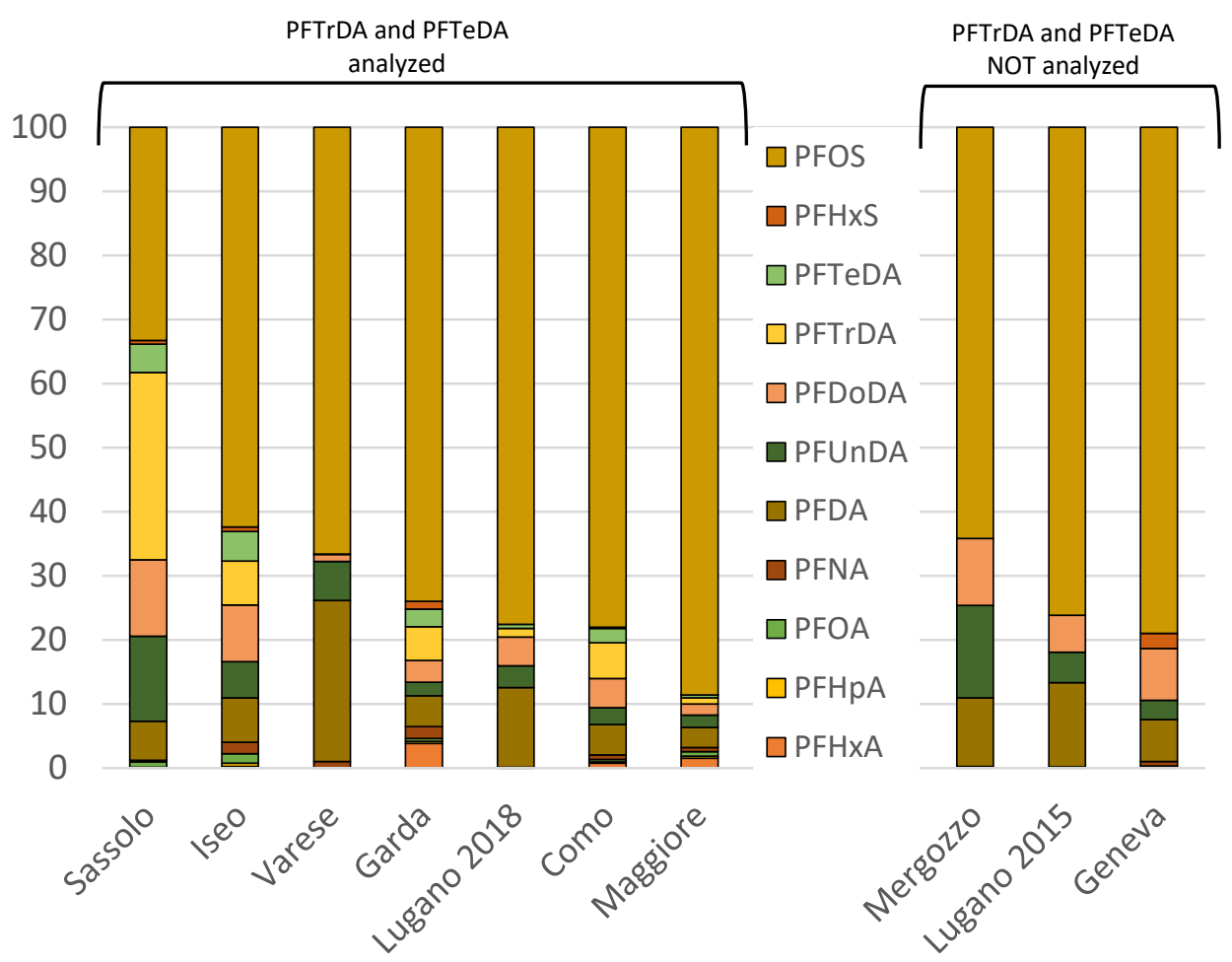

Fig. 3 Mean percentage composition of PFASs in the whole samples of each lake. Left: the lakes whose dataset includes PFTrDA and PFTeDA concentrations. Right: the lakes whose dataset does not include PFTrDA and PFTeDA concentrations.

\section{PFAS distribution in fish fractions}

Perfluoroalkyl acids (PFAAs) distribution among fish fractions was assessed for the most detected compounds, namely PFOS, PFNA, PFDA, PFUnDA and PFDoDA ( $N=38$ fish). Whatever the compound, the fraction that displayed the highest concentrations was the viscera, thus including liver and some blood, followed by the carcass, while the dorsal muscle had the lowest concentrations (Fig. 4). 
Fig.
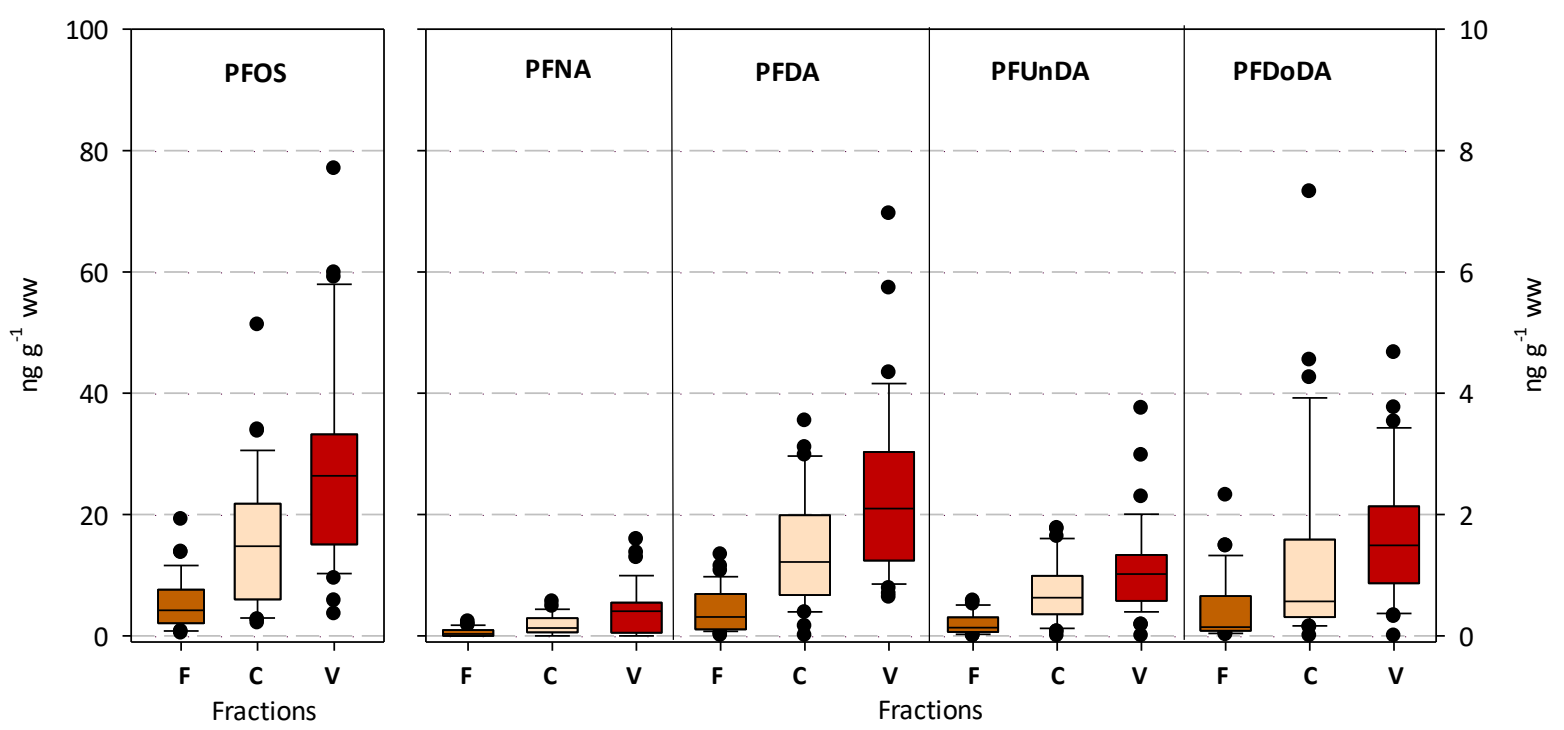

4:

Box-

whisker plot of the PFAS concentrations in the different fish fractions (all species and lakes together; F means fillet, $\mathrm{C}$ corresponds to carcass and $\mathrm{V}$ to viscera, incl. liver)

Nevertheless, the respective fraction loads differed among species (Fig. S3): the muscle (fillet) represented around $10 \%$ of the total body burden in shad for PFOS, PFDA, PFUnDA and PFDoDA, while it laid around $20 \%$ in burbot and roach; these differences were significant $(p=0.0003)$. Conversely, the loads in viscera (i.e. liver + entrails) were significantly higher $(p<0.0001)$ in shad (ca $35 \%$ ) than in burbot and roach (15 to $20 \%$ ) because of anatomic and physiological differences among these species.

Whole-body concentrations generally increased with concentrations in fillet, as illustrated in Figure S4 for the most detected compounds. However, since roach and burbot were analyzed only in Lake Geneva, whereas shad was analyzed only in Italian lakes, we chose to test separately the correlations (Mann-Kendall test followed by Theil-Sen regression). Results are reported in Table 4. Except for PFUnDA in roach and PFDoDA in shad, all regressions were significant, with mean slopes ranging from 1.59 to 3.54. The lack of significance for both PFDoDA in shad and PFUnDA in roach was probably due to the limited concentration gradient for these compounds in our dataset (Fig. S4). 
Table 4 - Correlation between fillet data and whole-body data

\begin{tabular}{|c|c|c|c|c|c|c|c|}
\hline \multirow[b]{2}{*}{ Chemical } & \multirow[b]{2}{*}{ Species } & \multicolumn{2}{|c|}{ Detection frequency (\%) } & \multirow[b]{2}{*}{$p$-value (МК) } & \multirow[b]{2}{*}{ Slope } & \multirow[b]{2}{*}{$95 \% \mathrm{Cl}$ of slope } & \multirow[b]{2}{*}{ Intercept } \\
\hline & & $\mathbf{F}$ & WB & & & & \\
\hline \multirow[t]{3}{*}{ PFNA } & A. agone & $83 \%$ & $96 \%$ & 0.004 & 2.28 & $1.039-3.676$ & 0.07 \\
\hline & L. lota & $100 \%$ & $100 \%$ & 0.018 & 2.29 & $0.377-3$ & -0.12 \\
\hline & R. rutilus & $0 \%$ & $100 \%$ & & & & \\
\hline \multirow[t]{3}{*}{ PFDA } & A. agone & $100 \%$ & $100 \%$ & 0.0002 & 2.78 & $1.602-3.599$ & 0.25 \\
\hline & L. lota & $100 \%$ & $100 \%$ & 0.003 & 2.53 & $1.691-3.053$ & -0.56 \\
\hline & R. rutilus & $100 \%$ & $100 \%$ & 0.011 & 1.59 & $0.751-2.085$ & 0.39 \\
\hline \multirow[t]{3}{*}{ PFUnDA } & A. agone & $96 \%$ & $100 \%$ & 0.0007 & 3.54 & $1.781-4.296$ & 0.10 \\
\hline & L. lota & $100 \%$ & $100 \%$ & 0.008 & 2.38 & $0.987-7$ & -0.24 \\
\hline & R. rutilus & $100 \%$ & $100 \%$ & 0.184 & NS & & \\
\hline \multirow[t]{3}{*}{ PFDoDA } & A. agone & $100 \%$ & $100 \%$ & 0.06 & NS & & \\
\hline & L. lota & $100 \%$ & $100 \%$ & 0.001 & 2.23 & $1.972-2.779$ & -0.34 \\
\hline & R. rutilus & $100 \%$ & $100 \%$ & 0.001 & 1.82 & $1.444-2.233$ & 0.20 \\
\hline \multirow[t]{3}{*}{ PFOS } & A. agone & $100 \%$ & $100 \%$ & 0.00001 & 2.19 & $1.74-2.931$ & 2.93 \\
\hline & L. lota & $100 \%$ & $100 \%$ & 0.008 & 1.61 & $1.06-2.71$ & 1.44 \\
\hline & R. rutilus & $100 \%$ & $100 \%$ & 0.003 & 1.85 & $0.94-2.134$ & -3.04 \\
\hline
\end{tabular}

In order to test whether the slopes of the regressions were different in the case of PFOS, we applied an ANCOVA to the dataset composed of fillet and whole-body concentrations for these three species, i.e. shad, roach and burbot $(N=34)$. The effect of species (qualitative variable) was significant $(p=0.043)$, meaning that the slopes of the respective regressions were different.

\section{DISCUSSION}

Technical aspects for monitoring compliance or for data comparison

Monitoring of chemical pollutants in fish is an important way to assess the contamination status of water bodies and identify the pollution sources especially in the case of lipophilic contaminants which are difficult to determine in water while tend to accumulate in biota. Starting from these

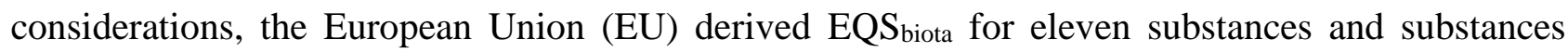
groups including one perfluoroalkyl compound, namely PFOS (2013/39/EU 2013).

It is necessary to consider many aspects (species selection, sampling period, selection of suitable matrices, etc.) when a fish sampling campaign is designed and implemented. The sampling strategies should be designed according to the purposes of the studies, but, sometimes, research studies must fit into existing monitoring programs for practical or logistical reasons. The Guidance Document n. 32 on Biota Monitoring under the Water Framework Directive (hereafter called GD-Biota) (EC 2014) addresses many of the controversial issues in biota sampling. However, it does not provide specific 
recommendations on all aspects because they are very influenced by the site-specific characteristics, such as e.g. availability of fish species, their exposure ways to contaminants which imply a wide variability in accumulation behavior. A recent article (Fliedner 2018) analyzed the available fish monitoring data of German Danube for some bioaccumulable compounds, including PFOS, to discuss some open questions such as the relationship between contaminant concentrations in fillet and whole fish and the use of normalization to overcome tissue and species-specific differences in accumulation. Since contaminant levels in fish are known to be influenced by a range of biological and environmental factors (EC 2014), natural variability within tissues and between samples should be minimized as much as possible to strengthen the comparison between different monitoring programs. One of the factors that most impacts the fish biology is seasonality. We did not find any statistical difference in the different seasons regarding both the analyzed PFASs and the considered fish species (shad and European perch). We do not have enough data to confirm the results for other species, but we can assume that the sampling season is less critical for PFASs than for legacy lipophilic substances (Fig. S1), as already demonstrated for zooplankton accumulation in the same subalpine lakes (Pascariello 2019).

When monitoring programs shall cover many water bodies, it is necessary to have flexibility in the choice of the fish species because we can monitor only species that are actually present in the sampling sites. But it is also necessary to evaluate how comparable the concentration data of different species are. In the present study, comparison of fish species was possible only between roach and burbot in Lake Geneva, shad and European perch in Lake Lugano and European perch and roach in Lake Varese. The differences between the couples of species for PFOS and long chain PFCA in fillet were not significant (Fig. S2). This result might be due to the limited sample size, or to the lack of distinction between feeding behaviors. Examining the PFAS concentrations of fish from the Rhône River, it was shown that the differences in concentrations between three species (Barbus barbus, Gobio gobio and Rutilus rutilus) could be explained by their diet, based on stomach contents, and the analysis of food sources (Babut 2017). We cannot exclude that the food webs are different in lotic and deep lentic environments, because a food web based on a benthic or detritus source (mainly allochthonous) could prevail in the former and a phytoplankton-based pelagic one in the latter, but we have no sufficient data to exploit the dataset in a more detailed way under this perspective.

There are other possible sources of variability such as $a$ ) the within-body contaminant distribution in the different fish tissues; $b$ ) the differences in accumulation among fish of different sizes of the same species and c) among different species from the same water body. One possible solution to overcome 
these intrinsic variabilities is the normalization of the fish concentrations against any biological components such as lipids, dry matter or protein, as suggested by GD-Biota.

It is known that chemical contaminants are not evenly distributed in fish. For example, the concentrations of hydrophobic substances tend to be higher in the liver than in the rest of fish but the difference widely disappears when the results are lipid-normalized (Jurgens 2013). The GD-Biota (EC 2014) already points out that lipid normalization is not appropriate for PFOS but suggests normalization against another parameter, such as dry weight, as a proxy for the total protein content. According to our dataset, concentrations of PFASs in viscera, which include liver and some blood, were higher than in the remaining fractions (carcass or fillet) (Fig. 4). If normalization succeeds in reducing the concentration differences between the fractions, the ratio between the normalized concentrations in the different fish fractions should approach the unit value. The comparison between the ratios of carcass-to-viscera and fillet-to-viscera concentrations, based both on fresh and dry weight, are reported in Table S13. The dry weight normalization was ineffective in reducing both the concentration differences between the fish fractions for any PFAS (i.e. the median values of the ratios did not change if based on fresh or dry weight) and their variability (expressed as RSD) (Table S13). These results agree with Fliedner (2018) study who demonstrated that normalizing to $26 \%$ dry mass as suggested by GD-Biota had a very partial effect in adjusting fillet and whole fish data for nonlipophilic substances such as PFOS.

Normalization based on proteins could be an effective alternative since it is known that PFASs preferentially bind to proteins (Kelly 2009; Houde 2011). However, total protein contents did not vary much among fish fractions in our dataset (Table S7). PFASs have high affinities only for specific proteins (Ng 2013; Cheng 2018; Zhong 2019), and thus normalization to the total protein content is not likely to improve data variability.

Finally, some studies also suggested that phospholipid binding could play a significant role in tissue distribution of PFASs (Armitage 2012; Droge 2019); for this reason, polar lipid content was determined in fractions of some dissected fish. The highest polar lipid content was measured in viscera (Table S7) that also presented the highest PFAS content (Tables 1-3; Fig. 4). The comparisons between the carcass-to-viscera and fillet-to-viscera ratios of concentrations, based on fresh weight, and the same ratios normalized to polar lipids are reported in Table S14 for PFAS congeners with data above the detection limits. The dataset is rather poor and no clear conclusion can be inferred: in the case of fillet-to-viscera ratio, the ratios for polar lipid normalized concentrations were similar to those expressed as fresh weight for all the substances (median values ranged from 0.21 to 0.35 ) and even an increase of the ratio variability (expressed as RSD) was detected. On the contrary, in the case 
of carcass-to-viscera ratios the polar lipid normalization improved the comparability between fractions (median values ranged from 0.59 to 0.79 ) without a substantial increase in variability (RSD). This suggests that polar lipids might be used as a surrogate for normalization of the viscera and carcass concentrations, at least for PFOS and long chain PFCAs. Due to the size limitation of our dataset, further studies are needed to strengthen this conclusion. Furthermore, it is important to underline that neither carcass nor viscera can be considered the ideal matrix to be monitored because they cannot be strictly defined.

Normalization of contaminant concentrations is also used to minimize the natural variability of collected fish at a sampling location. Again, it is suggested that normalization respect to lipid content and dry weight could be useful to account for this major influence on bioaccumulation in monitoring programs (EC 2014).

We already demonstrated that in the case of PFASs these two variables are not appropriate to account for variability between fish fractions, but we would like to assess whether this conclusion can also be extended to the normalization of different fish specimens in the same lake. The dataset for the most detected PFASs (PFOS, PFNA, PFDA, PFUnDA and PFDoDA) was analyzed as a whole, without distinction between species and lakes. The RSD values of fresh weight concentrations in fish fillet (the most populated dataset) ranged from 103 to 167\%. Any normalization procedure, if effective, should reduce the total variability of the dataset. Both lipid and dry weight normalization of the concentrations led to an increase in variability, RSD values ranging from 184 to 227\%, and from 111 to $244 \%$ for lipid or dry weight normalized concentrations respectively. The results confirm that neither lipid nor dry weight normalizations of PFAS concentrations have a positive effect on reducing the total variability. This finding is supported by the lack of correlation between the concentrations of PFASs and the fish lipid content or dry weights (In Fig. S5 of Supplemental Material plots for fillet samples of Lake Lugano are reported as an example).

PFOS is currently the only perfluorinated chemical regulated for water quality in European Union.

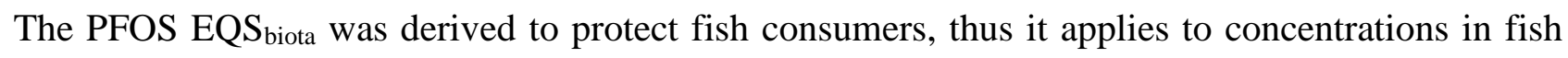
meat (fillets). Being more homogenous, the fillet is more easily analyzed, and yielded generally lower LODs and LOQs than other fish fractions in this study (Table S5). Nevertheless, the fillet was generally the fraction displaying the lowest detection rates, especially for short chain compounds (Tables 1-3). Carcasses and viscera presented higher concentrations than fillets for all long chain PFASs in this study (Fig. 4), consistent with previous works that showed similar distribution patterns (Martin 2003a; Martin 2003b; Peng 2010). Measurements in fillet would therefore be more appropriate, provided to have a fit for purpose LOQ. Nevertheless, it would be more relevant to use 
whole-body concentrations when the assessment of the risk of secondary poisoning for piscivorous fauna is needed. In this perspective knowing the relationships between fillet and whole-body concentrations should be very useful. Fliedner et al. recently proposed a simple linear model for extrapolating whole-body concentrations based on measurements in fillets (Fliedner 2018). Their model was based on pool samples of several species (bream, chub and perch) from one location in the Danube River. They obtained two different slopes, namely 1.93 when concentrations were normalized according to dw fraction, and 2.85 when they were not normalized, which are higher than those derived in the present work, but comprised in their confidence intervals, except for burbot (Table 4). Predicted whole-body concentrations of PFOS based on this model (ww slope) were correlated to measured whole-body concentrations $\left(R^{2}=0.75\right)$, but the slope of the regression between predicted and measured concentrations $(0.56 \pm 0.05)$ strongly deviated from one. This model tended to underestimate whole-body PFOS concentrations in more contaminated shad samples, and systematically overestimated whole-body PFOS concentrations in burbot and roach, up to $78 \%$. In less contaminated shad samples whole-body concentrations were also overestimated by more than $25 \%$. We therefore do not recommend using this generic equation for predicting PFOS whole-body concentrations for species not considered in Fliedner (2018). Consistent with the abovementioned ANCOVA results, a global model based on our data did not perform better than that of Fliedner (2018), suggesting that species and ecosystem specific models would probably be more relevant.

\section{Comparison with European lakes and North American Great Lakes}

This work presents the first survey of PFAS contamination in lake fish in a wide area covering the north and south sides of the Alps where the largest and deepest European lakes are present. Lakes are located in densely urbanized subalpine regions, which are characterized by dynamic economic activities, including tourism and industries (Eurostat 2020b). Being a large reservoir of freshwater for some of the most important European river basins, subalpine lake ecosystems must be protected from chemical pollution coming from industrial sources as well as everyday domestic uses. Due to their persistence and bioaccumulation potential, perfluoroalkyl acids are good tracers of the anthropic pressures on the chemical status of these precious freshwater ecosystems. PFAS concentrations in European lake fish are available mainly for smaller lakes in North Europa (Norway and Sweden) with sporadic data from impacted lakes in Germany and the Netherlands (Table S15). Compared with other European lakes, our data show that the subalpine lakes were generally in the lowest contamination range for PFOS and the $\sum$ PFAS, in the same order of magnitude as the least impacted Sweden and Norwegian lakes (Berger 2009; Hansen 2016). The highest PFOS concentrations in European lake fish (hundreds of ng/g ww) were measured in the lakes which are impacted by specific sources, such 
as the drainage from neighboring airports (Ahrens 2015; Filipovic 2015; Hansen 2016), the run-off from PFAS-amended soils (Holzer 2011), or the wastewater discharges (Schuetze 2010).

The most polluted lakes (L. Maggiore, Varese, Geneva and Lugano) in our study showed average fish concentrations ( $\sum$ PFAS from 10.7 to $28.1 \mathrm{ng} / \mathrm{g} \mathrm{ww}$ ) comparable to the least contaminated Laurentian Great Lakes, which are L. Superior and L. Michigan located upstream in the west (Stahl 2014; Remucal 2019). ¿PFAS in lake trout varied widely across the Great Lakes with a consistent spatial gradient, which increases from west to east, ranging from $11 \mathrm{ng} / \mathrm{g}$ in L. Superior to $24 \mathrm{ng} / \mathrm{g}$ in L. Michigan and $46 \mathrm{ng} / \mathrm{g}$ in L. Huron. The highest $\sum$ PFAS concentrations were measured in the further east lakes, L. Ontario (92 ng/g) and L. Erie (136 ng/g). On a mass basis, PFOS percentage on the $\sum$ PFAS ranged from $35 \%$ in Lake Superior to 64\% of PFASs in Lake Huron to $80-82 \%$ of PFASs in Lakes Erie and Ontario (Remucal 2019). In another study, PFOS was detected in 100\% of 157 Great Lakes fish samples from 18 species, with a median of $15 \mathrm{ng} / \mathrm{g}$ and a maximum concentration of 80 $\mathrm{ng} / \mathrm{g}$ in fillets (Stahl 2014), 2-3 times higher than our data (median $6.0 \mathrm{ng} / \mathrm{g}$ and a maximum of 50.5 ng/g, Table 1).

\section{Sources of PFASs in lakes}

The availability of a dataset of ten lakes from Lake Geneva to Lake Garda, which span about $400 \mathrm{~km}$ from north-west to south east in the Alps, gave us the possibility to study the sources and the transport mechanisms of PFAS in this area.

Together with subalpine deep and shallow lakes, we collected data also from two small natural Alpine lakes, Lakes Sassolo Lower and Upper, located in an uninhabited mountainous territory at more than $2000 \mathrm{~m}$ of altitude, in the Lake Maggiore catchment. The absence of direct sources allowed to estimate the contribution of atmospheric transport to PFAS contamination and to compare data with those collected in remote lakes in the French Alps (Ahrens 2010), in Sweden (Åkerblom 2017) and in the Faroe Islands and Greenland (Bossi 2015) (Table S15).

PFOS concentrations in fish from Sassolo Lakes (mean 0.4 \pm 0.3; median 0.3; range 0.2-0.8 ng/g ww) were close to the mean of pristine Swedish Lakes (mean 0.2; range <0.025-0.93 ng/g ww) (Åkerblom 2017). The median of long chain PFCAs (C9-C12) in Lakes Sassolo was about $0.7 \mathrm{ng} / \mathrm{g}$ ww which is the same as in all examined Swedish lakes (Åkerblom 2017). This value can be considered a continental background level in fish due to the atmospheric contribution, because in remote areas the long chain PFCAs necessarily originate from oxidative transformation of air-borne long chain fluorotelomer precursors (Schenker 2008; Benskin 2011).

It is interesting to note that in the remote lakes in Sweden, $\sum$ PFAS content decreases with the latitude but the relative $\sum$ LC-PFCA content increase ( $₫$ kerblom 2017). A similar trend, i.e. the decrease of 
total PFASs and the corresponding increase of long chain PFCAs respect to PFOS, was also observed in Great Lakes, moving from east to west as a function of the decrease in industrialization and urbanization (Remucal 2019). On the consequence, we studied the use of the ratio between PFOS and long chain PFCA concentrations in fish (Ratio PFOS/ $\sum$ LC-PFCA) as a proxy of the impact of human activities (Table S12). In our study, we added only C9-C12 PFCA in the $\sum$ LC-PFCA, because longer PFCAs (C13-C14) have not been analyzed in all lakes.

First of all, it should be noted that these ratios were very similar among carcass, liver and viscera (Table S12) and in some lakes also in fillets (e.g. Lake Geneva: 4.9 in fillet, 4.4 in carcass, 5.5 in liver and 5.5 in viscera, but Lake Maggiore 15.1 in fillet, 8.3 in carcass, and 8.0 in viscera). In the case of remote areas, PFOS/ $\sum$ LC-PFCA ratios measured in fish fillets from Sassolo Lakes ranged from 0.4 to 0.8 (with an anomalous value of 9.5). They were $\leq 0.3$ in liver of fish in French Alpine lakes (Åkerblom 2017), and most of them were $\leq 0.5$ in liver of fish caught at the Far Oer islands and Southern Greenland (Bossi 2015) (Table S15). These results suggest that a ratio PFOS/ $\sum$ LC-PFCA $<1$ in every monitoring tissue could be an indicator of the absence of direct water emission sources.

In general, the ratio PFOS/ $\sum$ LC-PFCA could be used as a tracer of the distance from the emission sources in remote areas, but in the urbanized and industrialized areas this ratio is more influenced by the presence of direct sources of PFOS or long chain PFCAs that are generally different from each other. In the subalpine lakes the median values of the ratio PFOS/ $\sum$ LC-PFCA for fillets (matrix with the amplest dataset) ranged from 1.9 of Lake Mergozzo to 15.1 of Lake Maggiore.

The main problem in interpreting these data is that the long chain PFCA releasing points into the environment have not been yet recognized together with the timing of release, given their high persistence and potential transformation from precursors. The investigation, recently carried out by the German Environmental Agency (Wirth 2019) and the European Chemical Agency (ECHA 2018) as support for preparing the restriction proposal under European REACH regulation, found no indication that these chemicals are used intentionally in any industrial sector within the EU. Applications containing PFCAs as impurities were seen to be of low relevance, while no direct or indirect uses of these substances could be identified. No manufacturers or users of C9-C14 PFCAs and only one importer have been identified in the EU (Wirth 2019). Potential environmental sources of long-chain PFCAs include the breakdown of their fluorotelomer alcohol (FTOH) precursors during wastewater and sewage treatment processes, the oxidation of their precursors in the atmosphere, and the degradation of commercial products containing their precursors (Ellis 2004; Ahrens 2011b). These precursors have been detected in various consumer articles and mixtures such as textiles, 
carpets, upholstery, paper, leather, toner, cleaning agents and carpet care solutions, sealants, floor waxes, paints and impregnating agents which might be imported into the EU (ECHA 2018).

Since long chain PFCA are ubiquitarian chemical compounds which are present in widespread products and industrial formulations, we tested the possibility to correlate $\sum$ LC-PFCA concentrations in fish with the extent of anthropic pressure in lake catchments, in order to assess the hypothesis that the main source for these compounds is the release from products used in everyday life.

As an index of the anthropic pressure in the catchment we propose the Degurba Index (DUI) calculated according to the Equation 3 (Table S6). The regression between DUI and medians of $\sum$ LCPFCA for the largest lakes was highly significant $\left(\mathrm{R}^{2}=0.941 ; \mathrm{p}=0.0013\right)$ (Fig. S6), suggesting that the emissions are strongly linked to the degree of urbanization of the lake catchment. Even if the regression between DUI and PFOS median concentrations was still significant $\left(\mathrm{R}^{2}=0.798 ; \mathrm{p}=\right.$ 0.016), PFOS experimental data were more scattered and presented higher residuals respect to the modelled ones. In particular, the highest residual was found for PFOS median of Lake Maggiore, suggesting that in this catchment there is an additional source other than those derived from the life cycle of consumer products. The ratio of the regression slopes of PFOS and $\sum$ LC-PFCA is $3.4( \pm 1.3)$ and this range could be considered an indication of the typical ratio PFOS/ 2 LC-PFCA of urbanized area, when no specific industrial sources are present.

\section{CONCLUSIONS}

Monitoring the accumulation of persistent substances such as long chain perfluoroalkyl acids in aquatic biota should be the method of choice in large and deep lakes to assess their quality status. Fish monitoring allows overcoming the problems of the high water dilution of the contaminants in these environments and gives a spatially and temporally integrated picture of the contamination. On the other hand, this tool raises some controversial issues in terms of procedure harmonization and data evaluation. For that reason monitoring protocols must take into account variabilities in water bodies' characteristics as well as in the accumulation mechanisms of contaminants.

Based on these considerations, we gathered data from different monitoring programs which gave us the possibility to discuss some technical aspects of biota monitoring and, at the same time, to obtain the first large survey of PFASs in European lakes of the subalpine region.

In particular, our approach tested the possibility to harmonize the monitoring protocols, especially in terms of fish species, seasonality, and fish matrix to be analyzed. The natural variability of fish should be minimized when designing and implementing a fish sampling campaign as far as possible by selecting the sampling period of by applying the data normalization. Our results suggest that the 
sampling season is not critical for PFAS and that neither lipid nor dry weight normalizations of PFAS concentrations have a positive effect on reducing the total variability both for PFOS and long chain PFCAs.

The data comparison and analysis demonstrated that the PFAS contamination in lake fish is generally correlated with the degree of the urbanization of the lake catchment, but it is sometimes difficult to compare absolute concentrations in lake fish, because the lake hydro-morphological characteristics such as volume and residence time have a substantial role in determining the chemical concentrations of persistent and mobile contaminants. In fact, we can find that some lowland lakes (Garda, Iseo, Como and Maggiore) have the same fish concentrations of long chain perfluorocarboxylic acids as in high altitude lakes. Long chain PFCAs do not have any dominant and specific industrial or human activity source, but they are more related to everyday use of products/urbanization and are most probably transported to remote areas as air-borne precursors. On the contrary PFOS might have specific sources, such as fire training activity, not ever linked to the catchment urbanization. The use of ratio PFOS/ $\sum$ LC-PFCA can help to identify remote areas where the only source is atmospheric (ratio is usually <1), while it can give an idea of the relative weights of sources of PFOS and longchain PFCA in lakes sited in urbanized areas. 


\section{REFERENCES}

2013/39/EU. 2013. Directive 2013/39/EU of the European Parliament and of the Council of 12 August 2013 amending Directives 2000/60/EC and 2008/105/EC as regards priority substances in the field of water policy., Official Journal of the European Union. pp L226/001 - L226/217.

Ahrens L. 2011a. Polyfluoroalkyl compounds in the aquatic environment: a review of their occurrence and fate. Journal of environmental monitoring : JEM 13:20-31. DOI: 10.1039/c0em00373e.

Ahrens L, Marusczak N, Rubarth J, Dommergue A, Nedjai R, Ferrari C, Ebinghaus R. 2010. Distribution of perfluoroalkyl compounds and mercury in fish liver from high-mountain lakes in France originating from atmospheric deposition. Environ Chem 7:422-428. DOI: 10.1071/EN10025.

Ahrens L, Norstrom K, Viktor T, Cousins AP, Josefsson S. 2015. Stockholm Arlanda Airport as a source of per- and polyfluoroalkyl substances to water, sediment and fish. Chemosphere 129:33-38. DOI: 10.1016/j.chemosphere.2014.03.136.

Ahrens L, Shoeib M, Harner T, Lee SC, Guo R, Reiner EJ. 2011b. Wastewater treatment plant and landfills as sources of polyfluoroalkyl compounds to the atmosphere. Environ Sci Technol 45:8098-8105. DOI: 10.1021/es1036173.

Åkerblom S, Negm N, Wu P, Bishop K, Ahrens L. 2017. Variation and accumulation patterns of poly- and perfluoroalkyl substances (PFAS) in European perch (Perca fluviatilis) across a gradient of pristine Swedish lakes. Sci Total Environ 599-600:1685-1692. DOI: 10.1016/j.scitotenv.2017.05.032.

Armitage JM, Arnot JA, Wania F. 2012. Potential role of phospholipids in determining the internal tissue distribution of perfluoroalkyl acids in biota. Environ Sci Technol 46:12285-12286. DOI: 10.1021/es304430r.

Babut M, Labadie P, Simonnet-Laprade C, Munoz G, Roger M-C, Ferrari BJD, Budzinski H, Sivade E. 2017. Per- and poly-fluoroalkyl compounds in freshwater fish from the Rhône River: Influence of fish size, diet, prey contamination and biotransformation. Sci Total Environ 605606:38-47. DOI: 10.1016/j.scitotenv.2017.06.111.

Beach SA, Newsted JL, Coady K, Giesy JP. 2006. Ecotoxicological evaluation of perfluorooctanesulfonate (PFOS). Rev Environ Contam Toxicol 186:133-174.

Benskin JP, Phillips V, St Louis VL, Martin JW. 2011. Source elucidation of perfluorinated carboxylic acids in remote alpine lake sediment cores. Environ Sci Technol 45:7188-7194. DOI: 10.1021/es2011176.

Berger U, Glynn A, Holmstrom KE, Berglund M, Ankarberg EH, Tornkvist A. 2009. Fish consumption as a source of human exposure to perfluorinated alkyl substances in Sweden - analysis of edible fish from Lake Vattern and the Baltic Sea. Chemosphere 76:799-804. DOI: 10.1016/j.chemosphere.2009.04.044.

Bossi R, Dam M, Riget FF. 2015. Perfluorinated alkyl substances (PFAS) in terrestrial environments in Greenland and Faroe Islands. Chemosphere 129:164-169. DOI: 10.1016/j.chemosphere.2014.11.044.

Bradford MM. 1976. A rapid and sensitive method for the quantitation of microgram quantities of protein utilizing the principle of protein-dye binding. Analytical biochemistry. Analytical biochemistry 72:248-254.

Cheng W, Ng CA. 2018. Predicting Relative Protein Affinity of Novel Per- and Polyfluoroalkyl Substances (PFASs) by An Efficient Molecular Dynamics Approach. Environ Sci Technol 52:79727980. DOI: 10.1021/acs.est.8b01268.

CIPAIS. Commissione Internazionale per la Protezione delle acque Italo-Svizzere (http://www.cipais.org/). 
CIPEL. Commission Internationale pour la Protection des Eaux du Léman -

https://www.cipel.org/en/

Dabrio Ramos M, van der Veen I, Emteborg H, JWeiss J, Schimmel H. 2015. Certification of the Mass Fraction of Perfluoralkyl Substances (PFASs) in FishTissue (pike-perch): IRMM-427, Report EUR 27429, Luxembourg: Publications Office of the European Union. JRC Technical Reports, EUR 27429 EN.

Dehouck P, Dabrio M, Cordeiro F, Cizek-Stroh A, Beatriz de la Calle MB. 2015. IMEP-42: Determination of PFASs in fish. Interlaboratory Comparison Report. JRC Technical Reports, EUR 27579 EN. Publications Office of the European Union.

Droge STJ. 2019. Membrane-Water Partition Coefficients to Aid Risk Assessment of Perfluoroalkyl Anions and Alkyl Sulfates. Environ Sci Technol 53:760-770.

EC. 2006. COMMISSION REGULATION (EC) No 1881/2006 of 19 December 2006 setting maximum levels for certain contaminants in foodstuffs (Text with EEA relevance). In Commission E, ed. Official Journal of the European Union, p. 20.

EC. 2014. Guidance Document No. 32 on Biota Monitoring (the Implementation of EQS biota) $_{\text {) }}$ under the Water Framework Directive, Technical Report - 2014 - 083.

ECHA. 2018. EU: Restriction on C9-C14 PFCAs proposed under REACH. Helsinki, Finland, p. 284.

Ellis DA, Martin JW, De Silva AO, Mabury SA, Hurley MD, Sulbaek Andersen MP, Wallington TJ. 2004. Degradation of Fluorotelomer Alcohols: A Likely Atmospheric Source of Perfluorinated Carboxylic Acids. Environ Sci Technol 38:3316-3321. DOI: 10.1021/es049860w.

Eurostat. 2014. Degree of Urbanisation: Shape file. European Commission [April 2019]. Available from: https://ec.europa.eu/eurostat/web/gisco/geodata/reference-data/populationdistribution-demography/degurba

Eurostat. 2020a. Degree of urbanisation (DEGURBA) Luxembourg: European Commission [April 2019]. Available from: https://ec.europa.eu/eurostat/web/degree-of-urbanisation/background

Eurostat. 2020b. Degree of Urbanisation: database. European Commission [April 2019]. Available from: https://ec.europa.eu/eurostat/data/database

Filipovic M, Woldegiorgis A, Norstrom K, Bibi M, Lindberg M, Osteras AH. 2015. Historical usage of aqueous film forming foam: a case study of the widespread distribution of perfluoroalkyl acids from a military airport to groundwater, lakes, soils and fish. Chemosphere 129:39-45. DOI: 10.1016/j.chemosphere.2014.09.005.

Fliedner A, Rudel H, Lohmann N, Buchmeier G, Koschorreck J. 2018. Biota monitoring under the Water Framework Directive: On tissue choice and fish species selection. Environ Pollut 235:129-140. DOI: 10.1016/j.envpol.2017.12.052.

Gewurtz SB, Backus SM, De Silva AO, Ahrens L, Armellin A, Evans M, Fraser S, Gledhill M, Guerra P, Harner T, Helm PA, Hung H, Khera N, Kim MG, King M, Lee SC, Letcher RJ, Martin P, Marvin C, McGoldrick DJ, Myers AL, Pelletier M, Pomeroy J, Reiner EJ, Rondeau M, Sauve M-C, Sekela M, Shoeib M, Smith DW, Smyth SA, Struger J, Spry D, Syrgiannis J, Waltho J. 2013. Perfluoroalkyl acids in the Canadian environment: Multi-media assessment of current status and trends. Environ Int 59:183-200. DOI: 10.1016/j.envint.2013.05.008.

Hansen S, Vestergren R, Herzke D, Melhus M, Evenset A, Hanssen L, Brustad M, Sandanger TM. 2016. Exposure to per- and polyfluoroalkyl substances through the consumption of fish from lakes affected by aqueous film-forming foam emissions - A combined epidemiological and exposure modeling approach. The SAMINOR 2 Clinical Study. Environ Int 94:272-282. DOI: 10.1016/j.envint.2016.05.030.

Holzer J, Goen T, Just P, Reupert R, Rauchfuss K, Kraft M, Muller J, Wilhelm M. 2011. Perfluorinated compounds in fish and blood of anglers at Lake Mohne, Sauerland area, Germany. Environ Sci Technol 45:8046-8052. DOI: 10.1021/es104391z.

Horppila J, Peltonen H. 1997. A bioenergetic approach on food consumption of roach (Rutilus rutilus (L)) in a eutrophic lake Archiv fur Hydrobiologie 139:207-222. 
Houde M, De Silva AO, Muir DC, Letcher RJ. 2011. Monitoring of perfluorinated compounds in aquatic biota: an updated review. Environ Sci Technol 45:7962-7973. DOI: 10.1021/es104326w.

Houde M, Martin JW, Letcher RJ, Solomon KR, Muir DCG. 2006. Biological Monitoring of Polyfluoroalkyl Substances: A Review. Environ Sci Technol 10:3643-3473. DOI: 10.1021/es052580b.

Jurgens MD, Johnson AC, Jones KC, Hughes D, Lawlor AJ. 2013. The presence of EU priority substances mercury, hexachlorobenzene, hexachlorobutadiene and PBDEs in wild fish from four English rivers. Sci Total Environ 461-462:441-452. DOI: 10.1016/j.scitotenv.2013.05.007.

Kamjunke N, Schmidt K, Pflungmacher S, Mehner T. 2002. Consumption of cyanobacteria by roach (Rutilus rutilus): useful or harmful to the fish? Freshwater Biology 47:243-250.

Kannan K, Tao L, Sinclair E, Pastva SD, Jude DJ, Giesy JP. 2005. Perfluorinated compounds in aquatic organisms at various trophic levels in a Great Lakes food chain. Arch Environ Contam Toxicol 48:559-566. DOI: 10.1007/s00244-004-0133-x.

Kelly BC, Ikononou MG, Blair JD, Surridge B, Hoover D, Grace R, Gobas FAPC. 2009. Perfluoroalkyl Contaminants in an Arctic Marine Food Web: Trophic Magnification and Wildlife Exposure. Environ Sci Technol 43:4037-4043.

Kottelat M, Freyhof J. 2007. Handbook of European Freshwater Fishes. Kottelat, Cornol and Freyhof, Berlin.

Lau C, Anitole K, Hodes C, Lai D, Pfahles-Hutchens A, Seed J. 2007. Perfluoroalkyl acids: a review of monitoring and toxicological findings. Toxicological sciences : an official journal of the Society of Toxicology 99:366-394. DOI: 10.1093/toxsci/kfm128.

Martin JW, Mabury SA, Solomon KR, Muir DC. 2003a. Bioconcentration and tissue distribution of perfluorinated acids in rainbow trout (Oncorhynchus mykiss). Environ Toxicol Chem 22:196-204.

Martin JW, Mabury SA, Solomon KR, Muir DCG. 2003b. Dietary accumulation of perfluorinated acids in juvenile rainbow trout (Oncorhynchus mykiss). Environ Toxicol Chem 22:189-195.

Mazzoni M, Ferrario C, Bettinetti R, Piscia R, Cicala D, Volta P, Borgå K, Valsecchi S, Polesello S. 2020. Trophic Magnification of Legacy (PCB, DDT and Hg) and Emerging Pollutants (PFAS) in the Fish Community of a Small Protected Southern Alpine Lake (Lake Mergozzo, Northern Italy). Water 12. DOI: 10.3390/w12061591.

Mazzoni M, Polesello S, Rusconi M, Valsecchi S. 2016. Liquid chromatography mass spectrometry determination of perfluoroalkyl acids in environmental solid extracts after phospholipid removal and on-line turbulent flow chromatography purification. Journal of chromatography A 1453:62-70. DOI: 10.1016/j.chroma.2016.05.047.

Ng CA, Hungerbuhler K. 2013. Bioconcentration of perfluorinated alkyl acids: how important is specific binding? Environ Sci Technol 47:7214-7223. DOI: 10.1021/es400981a.

Palacios LE, Wang T. 2005. Egg-yolk lipid fractionation and lecithin characterization. Journal of the American Oil Chemists' Society 82:571-578.

Pascariello S, Mazzoni M, Bettinetti R, Manca M, Patelli M, Piscia R, Valsecchi S, Polesello S. 2019. Organic Contaminants in Zooplankton of Italian Subalpine Lakes: Patterns of Distribution and Seasonal Variations. Water 11:1901. DOI: 10.3390/w11091901.

Peng H, Wei Q, Wan Y, Giesy JP, Li L, Hu J. 2010. Tissue Distribution and Maternal Transfer of Poly- and Perfluorinated Compounds in Chinese Sturgeon (Acipenser sinensis): Implications for Reproductive Risk. nviron Sci Technol 44.

Remucal CK. 2019. Spatial and temporal variability of perfluoroalkyl substances in the Laurentian Great Lakes. Environmental science Processes \& impacts 21:1816-1834. DOI: 10.1039/c9em00265k.

Riviere G, Sirot V, Tard A, Jean J, Marchand P, Veyrand B, Le Bizec B, Leblanc JC. 2014. Food risk assessment for perfluoroalkyl acids and brominated flame retardants in the French 
population: results from the second French total diet study. Sci Total Environ 491-492:176-183. DOI: 10.1016/j.scitotenv.2014.01.104.

Schenker U, Scheringer M, MacLeod M, Scheringer M, Cousins AP, Hungerbühler K. 2008. Contribution of Volatile Precursor Substances to the Flux of Perfluorooctanoate to the Arctic. Environ Sci Technol 42:3710-3716.

Schuetze A, Heberer T, Effkemann S, Juergensen S. 2010. Occurrence and assessment of perfluorinated chemicals in wild fish from Northern Germany. Chemosphere 78:647-652. DOI: 10.1016/j.chemosphere.2009.12.015.

Smedes F. 1999. Determination of total lipid using non-chlorinated solvents. The Analyst 124:1711-1718.

Solcà N. 2016. Lago di Lugano: indagine sulle sostanze pericolose, Contaminanti organici persistenti nella fauna ittica. Commissione internazionale per la protezione delle acque italosvizzere (CIPAIS), Programma triennale 2013 - 2015, Campagna 2015.

Solcà N. 2019. Lago di Lugano: Ricerca e monitoraggio di sostanze pericolose nella fauna ittica. Commissione internazionale per la protezione delle acque italo-svizzere (CIPAIS), Programma triennale 2016 - 2018 Campagna 2018.

Stahl LL, Snyder BD, Olsen AR, Kincaid TM, Wathen JB, McCarty HB. 2014. Perfluorinated compounds in fish from U.S. urban rivers and the Great Lakes. Sci Total Environ 499:185-195. DOI: $10.1016 /$ j.scitotenv.2014.07.126.

Steingruber S. 2018. Results from the participation of Switzerland to the International Cooperative Programme on Assessment and Monitoring Effects of Air Pollution on Rivers and Lakes (ICP Waters), Annual report 2018. Repubblica e Cantone Ticino Dipartimento del territorio.

UNEP-POPS. 2009. Stockholm Convention on Persistent Organic Pollutants, SC-4/17: Listing of perfluorooctane sulfonic acid, its salts and perfluorooctane sulfonyl fluoride.

UNEP-POPS. 2017. Stockholm Convention on Persistent Organic Pollutants, POPRC.13/4: Proposal to list perfluorohexane sulfonic acid (CAS No: 355-46-4, PFHxS), its salts and PFHxSrelated compounds in Annexes A, B and/or C to the Stockholm Convention on Persistent Organic Pollutants.

UNEP-POPS. 2019. Stockholm Convention on Persistent Organic Pollutants, SC-9/12: Listing of perfluorooctanoic acid (PFOA), its salts and PFOA-related compounds.

USEPA. 2016. Statistical Software ProUCL 5.1.00 for Environmental Applications for Data Sets with and without Nondetect Observations. https://www.epa.gov/land-research/proucl-software

Wirth O, Bliklen R, Rödig L, Wichmann P, Zimmermann T, Posner S, Hildenbrand J. 2019. on behalf of the German Environment Agency. Potential SVHC in environment and articles information collection with the aim to prepare restriction proposals for PFAS. UBA Texte 144/2019, Dessau-Roßlau, Germany, p. 172.

Zhao S, Zhu L, Liu L, Liu Z, Zhang Y. 2013. Bioaccumulation of perfluoroalkyl carboxylates (PFCAs) and perfluoroalkane sulfonates (PFSAs) by earthworms (Eisenia fetida) in soil. Environ Pollut 179:45-52. DOI: 10.1016/j.envpol.2013.04.002.

Zhong W, Zhang L, Cui Y, Chen M, Zhu L. 2019. Probing mechanisms for bioaccumulation of perfluoroalkyl acids in carp (Cyprinus carpio): Impacts of protein binding affinities and elimination pathways. Sci Total Environ 647:992-999. DOI: 10.1016/j.scitotenv.2018.08.099. 


\section{Supplemental Material}

Perfluoroalkyl substances (PFAS) contamination in fish from European lakes 


\section{Lake characteristics}

Table S1. Main characteristics of sampled lakes

\begin{tabular}{|c|c|c|c|c|c|c|c|c|c|c|}
\hline & Geneva & $\begin{array}{l}\text { Lake Sassolo } \\
\text { (Upper) }\end{array}$ & $\begin{array}{l}\text { Lake Sassolo } \\
\quad \text { (Lower) }\end{array}$ & Mergozzo & Maggiore & Varese & Lugano & Como & Iseo & Garda \\
\hline Altitude (m a.s.l.) & 372 & 2,128 & 2,074 & 195 & 193 & 238 & 271 & 198 & 186 & 65 \\
\hline Area $\left(\mathbf{k m}^{2}\right)$ & 580 & 0.08 & 0.05 & 1.81 & 213 & 15 & 49 & 146 & 61 & 368 \\
\hline Maximum depth (m) & 310 & 29 & 33 & 74 & 370 & 26 & 288 & 425 & 251 & 350 \\
\hline Mean depth (m) & 154 & 13 & 11 & 45 & 178 & 11 & 134 & 154 & 123 & 133 \\
\hline Volume $\left(\mathbf{k m}^{3}\right)$ & 89 & 0.001 & 0.0005 & 0.8 & 37 & 0.2 & 6.5 & 22 & 8 & 49 \\
\hline Catchment area $\left(\mathbf{k m}^{2}\right)$ & 7,975 & 1 & $1.78^{*}$ & 10 & $6,599^{£}$ & 112 & 566 & 4,508 & 1,842 & 2,290 \\
\hline Main inflow & Rhône & & & Rio Rescina & $\begin{array}{l}\text { Ticino, } \\
\text { Toce }\end{array}$ & Brabbia & $\begin{array}{l}\text { Vedeggio, } \\
\text { Cassarate }\end{array}$ & Adda & Oglio & Sarca \\
\hline Main outflow & Rhône & $\begin{array}{c}\text { Water flows } \\
\text { in Lake } \\
\text { Sassolo } \\
\text { (Lower) }\end{array}$ & $\begin{array}{c}\text { Maggia } \\
\text { (flowing in } \\
\text { Lake } \\
\text { Maggiore) }\end{array}$ & $\begin{array}{l}\text { Mergozzo } \\
\text { (flowing in } \\
\text { Lake } \\
\text { Maggiore) }\end{array}$ & Ticino & $\begin{array}{c}\text { Bardello } \\
\text { (flowing in } \\
\text { Lake } \\
\text { Maggiore) }\end{array}$ & $\begin{array}{c}\text { Tresa } \\
\text { (flowing in } \\
\text { Lake } \\
\text { Maggiore) }\end{array}$ & Adda & Oglio & Mincio \\
\hline $\begin{array}{l}\text { Mean outflow } \\
\text { discharge } \\
\left(\mathrm{m}^{3} \mathrm{~s}^{-1}\right)\end{array}$ & 251 & & & & 291 & 2.5 & 25 & 158 & 59 & 58 \\
\hline $\begin{array}{l}\text { Theoretical retention } \\
\text { time (years) }\end{array}$ & 11.4 & & & 6 & 4.1 & 1.7 & 8.3 & 12.7 & $4.5 / 7.2$ & 26.6 \\
\hline Total $P\left(\mu g P^{-1}\right)$ & 20 & $<10$ & $<10$ & $<10$ & 10 & 80 & $\begin{array}{l}20 \text { (northern } \\
\text { basin) } \\
40 \text { (southern } \\
\text { basin) }\end{array}$ & 25 & 70 & 18 \\
\hline $\begin{array}{l}\text { O}_{2} \text { hypolimnetic } \\
\left(\mathrm{mg} \mathrm{L}^{-1}\right)\end{array}$ & $<4$ & 9 & 9 & $<4$ & 8 & $<4$ & $<4$ & 8 & $<4$ & 8 \\
\hline Catchment inhabitants & $1,083,431$ & - & - & 2,151 & 923,861 & 71,497 & 290,000 & 555,769 & 191,527 & 156,300 \\
\hline
\end{tabular}

*Includes the catchment of Lake Sassolo (Upper); ${ }^{£}$ Includes the catchments of Lakes Sassolo, Mergozzo, Varese and Lugano 


\section{Fish characteristics}

Table S2. Biological and ecological characteristics of the sampled species

\begin{tabular}{|c|c|c|c|c|c|c|c|}
\hline Species & $\begin{array}{l}\text { Common } \\
\text { name }\end{array}$ & Family & Habitat & Diet & $\begin{array}{c}\text { Fishbase Trophic } \\
\text { Level (based on } \\
\text { model) }\end{array}$ & Sex maturity & Spawning \\
\hline Lota Lota & Burbot & Lotidae & Demersal & $\begin{array}{l}\text { Smaller individuals: insect larvae, } \\
\text { crayfish, mollusks, other invertebrates. } \\
\text { Larger individuals: fish }\end{array}$ & $3.8 \pm 0.2$ & $\begin{array}{l}\text { Males at } 2 \text { years, } \\
\text { females at } 3 \text { years }\end{array}$ & November-March \\
\hline Rutilus rutilus & $\begin{array}{l}\text { Common } \\
\text { roach }\end{array}$ & Cyprinidae & Benthopelagic & $\begin{array}{l}\text { Mainly benthic invertebrates, } \\
\text { zooplankton, plant material and detritus }\end{array}$ & $3.0 \pm 0.0$ & $\begin{array}{l}\text { Males at 2-3 years, } \\
\text { females at 3-4 years }\end{array}$ & \\
\hline Alosa agone & Agone & Clupeidae & Pelagic & $\begin{array}{l}\text { Mainly cladocerans and copepods, also } \\
\text { small fish }\end{array}$ & $3.8 \pm 0.4$ & $\begin{array}{l}\text { Males at 2-3 years, } \\
\text { females at 3-4 years }\end{array}$ & June-August \\
\hline $\begin{array}{l}\text { Coregonus } \\
\text { lavaretus }\end{array}$ & $\begin{array}{l}\text { European } \\
\text { whitefish }\end{array}$ & Salmonidae & Demersal & $\begin{array}{l}\text { Planktonic crustaceans, or larger benthic } \\
\text { crustaceans in brackish water }\end{array}$ & $3.1 \pm 0.0$ & & December \\
\hline $\begin{array}{l}\text { Salvelinus } \\
\text { alpinus }\end{array}$ & Arctic char & Salmonidae & Benthopelagic & $\begin{array}{l}\text { Planktonic crustaceans, amphipods, } \\
\text { molluscs, insects and fish }\end{array}$ & $4.4 \pm 0.5$ & $4-10$ years & September -December \\
\hline Perca fluviatilis & $\begin{array}{l}\text { European } \\
\text { perch }\end{array}$ & Percidae & Demersal & $\begin{array}{l}\text { Predatory and opportunistic diurnal } \\
\text { feeder, both invertebrates and fish }\end{array}$ & $4.4 \pm 0.0$ & $\begin{array}{l}\text { Males at } 1-2 \text { years, } \\
\text { females at } 2-4 \text { years }\end{array}$ & February-July \\
\hline $\begin{array}{l}\text { Oncorhynchus } \\
\text { mykiss }\end{array}$ & $\begin{array}{l}\text { Rainbow } \\
\text { trout }\end{array}$ & Salmonidae & Benthopelagic & $\begin{array}{l}\text { Variety of aquatic and terrestrial } \\
\text { invertebrates and small fish }\end{array}$ & $4.1 \pm 0.3$ & $\begin{array}{l}\text { Males at } 2 \text { years, } \\
\text { females at } 3 \text { years }\end{array}$ & $\begin{array}{l}\text { November-May in the } \\
\text { Northern hemisphere }\end{array}$ \\
\hline Salmo trutta & Trout & Salmonidae & Demersal & $\begin{array}{l}\text { Predatory and opportunistic. Molluscs, } \\
\text { crustaceans and small fish }\end{array}$ & $3.4 \pm 0.1$ & 3 - 4 years & \\
\hline
\end{tabular}


Table S3. Sampling and biometric values of the fish samples (see excel file). n.d. not determined 


\section{Analysis}

\section{Protein content evaluation}

Protein content evaluation was conducted on fillets, carcasses and viscera of selected fish of Lake Iseo, Lake Como and Lake Garda, according to Bradford (1976). The Bradford method is a colorimetric method based on the shift of absorbance following the bond between the proteins and the dye Coomassie blue (Coomassie Brilliant Blue G-250; CBBG; Bradford reagent). Samples were singularly weighed $(\sim 0.2 \mathrm{~g})$ and homogenized in a $100 \mathrm{mM}$ phosphate buffer $(100 \mathrm{mM} \mathrm{KCl}, 1 \mathrm{mM}$ EDTA, pH 7.4) added with specific protease inhibitor (1:100 v/v) and dithiothreitol (DTT, $100 \mathrm{mM})$. The protein content was evaluated in triplicate on the supernatant ( 99 fraction) obtained by the centrifugation at $16,000 \times \mathrm{g}$ for $20 \mathrm{~min}$ of the raw homogenate. In detail, $5 \mu \mathrm{L}$ of sample was added to a mix of $1450 \mu \mathrm{L}$ of Bradford reagent and $45 \mu \mathrm{L}$ of $100 \mathrm{mM}$ phosphate buffer $(100 \mathrm{mM} \mathrm{KCl}, 1$ $\mathrm{mM}$ EDTA, protease inhibitor, DTT) in order to be read at $\lambda=595 \mathrm{~nm}$, by means of a Genova Bio spectrophotometer (Jenway). The obtained values were normalized using a standard calibration curve prepared with bovine serum albumin (BSA; $2 \mathrm{mg} / \mathrm{L}$ ). The protein content was expressed as $\mathrm{mg} / \mathrm{mL}$ (mg proteins / $\mathrm{mL}$ ) and as $\mathrm{mg} / \mathrm{g}$ (mg proteins / sample weight). The protein content was calculated using a standard calibration curve prepared with five dilution of bovine serum albumin (BSA; mother stock: $2 \mathrm{mg} / \mathrm{L}$ ) and expressed as $\mathrm{mg} / \mathrm{g}$ (mg proteins / sample weight).

\section{Polar lipid extraction}

The extraction polar lipids was conducted o on fillets, carcasses and viscera of selected fish of Lake Iseo, Lake Como and Lake Garda, according to a protocol developed by Palacios (2005) with slight adjustment. In detail, the sample taken by each fish was weightedsamples were singularly weighted ( $0.2 \mathrm{~g}$ ), homogenized with $10 \mathrm{~mL}$ of ethanol (95\%) and centrifuged at 19,000 $\times \mathrm{g}$ for $5 \mathrm{~min}$. The supernatant containing polar lipids, some neutral lipids and water was transferred and stored in a separatory funnel. Moreover, the remaining pellet was washed twice with $5 \mathrm{~mL}$ of hexane (10 minutes each) and twice with $10 \mathrm{~mL}$ of ethanol (95\%) in order to extract the residual lipids, and then the obtained suspension was transferred to the separatory funnel. The separatory funnel was gently mixed and left to equilibrate for 2 hours in order to allow the phase separation. The I phase (ethanol), containing the polar lipids, was removed and transferred in a glass bottle $(\sim 30 \mathrm{~mL})$ and then combined with the supernatant of a second wash of ethanol (90\%), performed in order to extract the residual polar lipids. Furthermore, the ethanol was evaporated and the polar lipids content was determined gravimetrically. The phase II (hexane; $20 \mathrm{~mL}$ ), was transferred to a glass flask, dried by rotary evaporation and the neutral lipids content was determined gravimetrically. 


\section{PFAS chemical analysis}

\section{Chemicals and Standards}

All reagents were analytical reagent grade. LC-MS grade Chromasolv acetonitrile and concentrated formic acid were purchased from Sigma-Aldrich. Water (<18 $\mathrm{M} \Omega \mathrm{cm}$ resistivity) was produced by a Millipore Direct-QUV water purification system (Millipore, Bedford, MA, USA). HybridSPE®Phospholipid Ultra cartridges (30 mg, 1 mL SPETubes) were obtained by Sigma Aldrich (St. Louis, Missouri, USA).

SPE Oasis WAX (150 mg, $6 \mathrm{~mL}$ ) were obtained by Waters (Manchester, England) and carbon SPE (500mg, $6 \mathrm{~mL}$ ) by Sigma Aldrich (Saint-Quentin-Fallavier, France).

Certified PFAS native compounds and isotope-labelled internal standards (ISs) were purchased from Wellington Laboratories, Inc. (Guelph, Ontario, Canada). PFAC-MXC Stock Solution containing native PFCAs and PFASs was diluted in acetonitrile to prepare calibration standard solutions. Masslabelled MPFAC-MXA solution (Wellington Laboratories, Inc.) was diluted in acetonitrile (40 $\mu \mathrm{g} / \mathrm{L})$ for the preparation of the stable isotope labelled solution used as internal standard mixture (SIL-IS). Details on the analyte names, abbreviations and corresponding IS are reported in Table S4 and S4b.

\section{Sample extraction and PFAS analysis at Water Research Institute}

The extraction of fish fractions was carried according to Mazzoni (2016). Briefly, few grams of homogenized pooled samples were weighed (viscera: $3 \mathrm{~g} \mathrm{ww}$; muscle: $10 \mathrm{~g} \mathrm{ww}$; carcass: $5 \mathrm{~g} \mathrm{ww}$ ) into a $50 \mathrm{~mL}$ polypropylene (PP) centrifuge tube and spiked with $100 \mu \mathrm{L}$ of SIL-IS solution (40 $\mu \mathrm{g} / \mathrm{L})$. Samples were extracted by sonication in an acidified water and acetonitrile (10:90 v/v) solution (1.5 mL of water and acetonitrile solution per gram of fresh sample) and subsequent purification on $\mathrm{MgSO}_{4} / \mathrm{NaCl}$. To remove phospholipids, volume reduced extracts $(1 \mathrm{~mL})$ were filtered through HybridSPE®Phospholipid Ultra cartridges, previously cleaned with $3 \mathrm{~mL}$ of acetonitrile and $50 \mu \mathrm{L}$ of formic acid ( 1 cartridge for carcass and muscle extract and 2 cartridges for viscera extracts). PFAS in the final extract were determined by liquid chromatography tandem mass spectrometry (UHPLCMS/MS) coupled to a turbulent flow chromatography (TFC) for the online purification of the extracts (Mazzoni 2016).

Table S4 lists the MS/MS transitions and collision energies applied for the different target analytes and isotope labelled standards. For all the analytes, one precursor and two product ions were monitored. Calibration curve standards were prepared using mixed standard solutions in acetonitrile, which were acidified to $\mathrm{pH} 3$ and spiked with SIL-IS by adding $50 \mu \mathrm{L}$ of concentrated formic acid and $100 \mu \mathrm{L}$ of the diluted SIL-IS solution $\left(40 \mu \mathrm{g} \mathrm{L}^{-1}\right)$ to $0.9 \mathrm{~mL}$ of native standard solution before injection. Quantification was performed by isotopic dilution method and calibration curves were acquired before each analytical run.

\section{Sample extraction and PFAS analysis in LABERCA}

The analytical method was developed to determine the concentration of 5 perfluoroalkyl sulfonates and 9 perfluorocarboxylic acids (Riviere 2014). The samples were freeze-dried, supplemented by

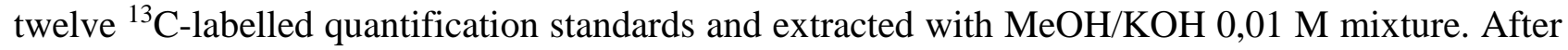
extraction, solvent collection and evaporation, the extracts were purified onto two consecutive SPE 
columns (Weak anion exchange and carbon stationnarystationary phase). Final, purified extracts were analysed by LC-ESI(-)-MS/MS. At least two diagnostics transitions per analyte were monitored (except for PFBA and PFPA). Quantification was performed according to isotope dilution principles. Table S4b lists the MS/MS transitions and collision energies applied for the different target analytes and isotope labelled standards.

Table S4a. List of PFAS compounds targeted in the present study, corresponding internal standards (IS) and LC/MS/MS parameters for all target analytes and internal standards.

\begin{tabular}{|c|c|c|c|c|c|}
\hline Target analytes & Abbreviation & $\begin{array}{l}\text { Precursor ion } \\
(\mathrm{m} / \mathrm{z})\end{array}$ & $\begin{array}{l}\text { Product } \\
\text { ions }(m / z)\end{array}$ & $\begin{array}{c}\text { Collision } \\
\text { energy }\end{array}$ & $\begin{array}{l}\text { Corresponding } \\
\text { IS } \\
\end{array}$ \\
\hline \multirow{2}{*}{ Perfluorohexanoic acid } & \multirow{2}{*}{ PFHxA } & \multirow{2}{*}{312.9} & 119.1 & 22 & \multirow{2}{*}{${ }^{13} \mathrm{C} 2$-PFHxA } \\
\hline & & & 268.9 & 11 & \\
\hline \multirow{2}{*}{ Perfluoroheptanoic acid } & \multirow{2}{*}{ PFHpA } & \multirow{2}{*}{362.9} & 169.0 & 18 & \multirow{2}{*}{${ }^{13} \mathrm{C} 4-\mathrm{PFOA}$} \\
\hline & & & 318.9 & 12 & \\
\hline \multirow{2}{*}{ Perfluorooctanoic acid } & \multirow{2}{*}{ PFOA } & \multirow{2}{*}{412.9} & 169.0 & 19 & \multirow{2}{*}{${ }^{13} \mathrm{C} 4$-PFOA } \\
\hline & & & 368.9 & 13 & \\
\hline \multirow{2}{*}{ Perfluorononanoic acid } & \multirow{2}{*}{ PFNA } & \multirow{2}{*}{462.9} & 218.9 & 18 & \multirow{2}{*}{${ }^{13} \mathrm{C} 5$-PFNA } \\
\hline & & & 418.9 & 13 & \\
\hline \multirow{2}{*}{ Perfluorodecanoic acid } & \multirow{2}{*}{ PFDA } & \multirow{2}{*}{512.9} & 268.9 & 18 & \multirow{2}{*}{${ }^{13} \mathrm{C} 2$-PFDA } \\
\hline & & & 468.9 & 13 & \\
\hline \multirow{2}{*}{ Perfluoroundecanoic acid } & \multirow{2}{*}{ PFUnDA } & \multirow{2}{*}{562.9} & 268.8 & 20 & \multirow{2}{*}{$\begin{array}{c}{ }^{13} \mathrm{C} 2- \\
\text { PFUnDA }\end{array}$} \\
\hline & & & 518.8 & 14 & \\
\hline \multirow{2}{*}{ Perfluorododecanoic acid } & \multirow{2}{*}{ PFDoDA } & \multirow{2}{*}{612.9} & 318.8 & 20 & \multirow{2}{*}{$\begin{array}{c}{ }^{13} \mathrm{C} 2- \\
\text { PFDoDA }\end{array}$} \\
\hline & & & 568.9 & 14 & \\
\hline \multirow{2}{*}{ Perfluorotridecanoic acid } & \multirow{2}{*}{ PFTrDA } & \multirow{2}{*}{662.9} & 619.0 & & ${ }^{13} \mathrm{C} 2-$ \\
\hline & & & 369.0 & 15 & PFDoDA \\
\hline Perfluorotetradecanoic acid & PETeDA & 7129 & 669.0 & 15 & ${ }^{13} \mathrm{C} 2-$ \\
\hline Perfluorotetradecanoic acid & PFIEDA & 712.9 & 419.0 & 15 & PFDoDA \\
\hline & & 3090 & 80.1 & 38 & \\
\hline Perfluorohexane sulphonate & PFHXS & 398.9 & 99.0 & 34 & ${ }^{10} \mathrm{O} 2-\mathrm{PFHXS}$ \\
\hline & & & 80.3 & 45 & ${ }^{13} \mathrm{C} 4 \mathrm{DEOS}$ \\
\hline Perfluorooctane sulphonate* & PFOS * & 498.9 & 99.1 & 45 & ${ }^{15} \mathrm{C} 4-\mathrm{PFOS}$ \\
\hline $\begin{array}{l}\text { Perfluoro-n- }\left[{ }^{13} \mathrm{C} 2\right] \text { hexanoic } \\
\text { acid }\end{array}$ & ${ }^{13} \mathrm{C}_{2}$-PFHxA & 314.9 & 269.9 & 11 & $\mathrm{n} / \mathrm{a}$ \\
\hline $\begin{array}{l}\text { Perfluoro-n- }\left[{ }^{13} \mathrm{C} 4\right] \text { octanoic } \\
\text { acid }\end{array}$ & ${ }^{13} \mathrm{C}_{4}-\mathrm{PFOA}$ & 416.9 & 371.9 & 13 & $\mathrm{n} / \mathrm{a}$ \\
\hline $\begin{array}{l}\text { Perfluoro-n- }\left[{ }^{13} \mathrm{C} 5\right] \text { nonanoic } \\
\text { acid }\end{array}$ & ${ }^{13} \mathrm{C}_{5}$-PFNA & 467.9 & 422.9 & 13 & $\mathrm{n} / \mathrm{a}$ \\
\hline $\begin{array}{l}\left.\text { Perfluoro-n- }-{ }^{[13} \mathrm{C} 2\right] \text { decanoic } \\
\text { acid }\end{array}$ & ${ }^{13} \mathrm{C}_{2}$-PFDA & 514.9 & 469.9 & 13 & $\mathrm{n} / \mathrm{a}$ \\
\hline $\begin{array}{l}\text { Perfluoro-n- }\left[{ }^{13} \mathrm{C} 2\right] \text { undecanoic } \\
\text { acid }\end{array}$ & ${ }^{13} \mathrm{C}_{2}$-PFUnDA & 564.9 & 519.8 & 14 & $\mathrm{n} / \mathrm{a}$ \\
\hline $\begin{array}{l}\text { Perfluoro-n- }\left[{ }^{13} \mathrm{C} 2\right] \text { dodecanoic } \\
\text { acid }\end{array}$ & ${ }^{13} \mathrm{C}_{2}$-PFDoDA & 614.9 & 569.9 & 14 & $\mathrm{n} / \mathrm{a}$ \\
\hline $\begin{array}{l}\text { Perfluoro-n-hexane }\left[{ }^{18} \mathrm{O} 2\right] \\
\text { sulphonate }\end{array}$ & ${ }^{18} \mathrm{O}_{2}-\mathrm{PFHxS}$ & 402.9 & 103.0 & 34 & $\mathrm{n} / \mathrm{a}$ \\
\hline $\begin{array}{l}\text { Perfluoro-n-octane }\left[{ }^{13} \mathrm{C} 4\right] \\
\text { sulphonate }\end{array}$ & ${ }^{13} \mathrm{C}_{4}$-PFOS & 502.9 & 99.1 & 45 & $\mathrm{n} / \mathrm{a}$ \\
\hline
\end{tabular}


n/a not applicable; *sum of linear and branched isomers

Table S4b. List of PFAS compounds, corresponding internal standards (IS) and LC/MS/MS parameters for all target analytes and internal standards analysed in LABERCA.

\begin{tabular}{|c|c|c|c|c|c|}
\hline Target analytes & Abbreviation & $\begin{array}{c}\text { Precursor ion } \\
(\mathrm{m} / \mathrm{z})\end{array}$ & $\begin{array}{c}\text { Product } \\
\text { ions }(\mathrm{m} / \mathrm{z})\end{array}$ & $\begin{array}{c}\text { Collision } \\
\text { energy }\end{array}$ & $\begin{array}{c}\text { Corresponding } \\
\text { IS } \\
\end{array}$ \\
\hline Perfluorobutanoic acid & PFBA & 213 & 169 & 5 & ${ }^{13} \mathrm{C} 2$-PFBA \\
\hline Perfluoropentanoic acid & PFPeA & 263 & 219 & 5 & ${ }^{13} \mathrm{C} 2$-PFBA \\
\hline \multirow{2}{*}{ Perfluorohexanoic acid } & \multirow{2}{*}{ PFHxA } & \multirow{2}{*}{312.9} & 118.9 & 15 & \multirow{2}{*}{${ }^{13} \mathrm{C} 5-\mathrm{PFHxA}$} \\
\hline & & & 268.9 & 5 & \\
\hline \multirow{2}{*}{ Perfluoroheptanoic acid } & \multirow{2}{*}{ PFHpA } & \multirow{2}{*}{362.9} & 169.0 & 10 & \multirow{2}{*}{${ }^{13} \mathrm{C} 4-\mathrm{PFHpA}$} \\
\hline & & & 318.9 & 5 & \\
\hline \multirow{2}{*}{ Perfluorooctanoic acid } & \multirow{2}{*}{ PFOA } & \multirow{2}{*}{412.9} & 169.0 & 15 & \multirow{2}{*}{${ }^{13} \mathrm{C} 4-\mathrm{PFOA}$} \\
\hline & & & 368.9 & 10 & \\
\hline \multirow{2}{*}{ Perfluorononanoic acid } & \multirow{2}{*}{ PFNA } & \multirow{2}{*}{462.9} & 168.9 & 15 & \multirow{2}{*}{${ }^{13} \mathrm{C} 5$-PFNA } \\
\hline & & & 418.9 & 5 & \\
\hline \multirow{2}{*}{ Perfluorodecanoic acid } & \multirow{2}{*}{ PFDA } & \multirow{2}{*}{512.9} & 218.9 & 15 & \multirow{2}{*}{${ }^{13} \mathrm{C} 2$-PFDA } \\
\hline & & & 468.9 & 5 & \\
\hline \multirow{2}{*}{ Perfluoroundecanoic acid } & \multirow{2}{*}{ PFUnDA } & \multirow{2}{*}{562.9} & 268.9 & 15 & \multirow{2}{*}{${ }^{13} \mathrm{C} 7-\mathrm{PFUnA}$} \\
\hline & & & 518.9 & 5 & \\
\hline \multirow{2}{*}{ Perfluorododecanoic acid } & \multirow{2}{*}{ PFDoDA } & \multirow{2}{*}{612.9} & 168.9 & 25 & \multirow{2}{*}{$\begin{array}{c}{ }^{13} \mathrm{C} 2- \\
\text { PFDoDA }\end{array}$} \\
\hline & & & 568.9 & 5 & \\
\hline \multirow{2}{*}{ Perfluorobutane sulphonate } & \multirow{2}{*}{ PFBS } & \multirow{2}{*}{299} & 80 & 40 & \multirow{2}{*}{${ }^{18} \mathrm{O} 2-\mathrm{PFHxS}$} \\
\hline & & & 99 & 40 & \\
\hline \multirow{2}{*}{ Perfluorohexane sulphonate } & PFHxS & 399 & 80 & 50 & ${ }^{18} \mathrm{O} 2-\mathrm{PFHxS}$ \\
\hline & & & 99 & 50 & \\
\hline Perfluorohentane sulnhonate & PFHnS & 449 & 80 & 45 & ${ }^{13} \mathrm{C} 4$-PFOS \\
\hline reminuoromeptante suippionate & гепру & 449 & 99 & 45 & C4-ז厂 \\
\hline Perfluorooctane sulnhonate & PFOS & 490 & 80 & 45 & ${ }^{13} \mathrm{C} 4 \mathrm{PFOS}$ \\
\hline Permuorooctane suipnonate & PFUS & 499 & 99 & 45 & C4-PFUS \\
\hline Perfluorodecane sulnhonate & PEDS & 599 & 80 & 50 & ${ }^{13} \mathrm{C} 4$-PFOS \\
\hline & & & 99 & 50 & \\
\hline
\end{tabular}


Table S5. Limits of Detection (LOD) and Limits of Quantification (LOQ) in fish tissue, estimated in the Water Research Institute laboratory, according to the ISO Standard 6107-2: 2006, as respectively, three-fold and tenfold the standard deviation of an extract of biological tissue fortified at $1 \mu \mathrm{g} / \mathrm{L}$.

\begin{tabular}{|c|c|c|c|c|c|c|}
\hline \multirow[b]{2}{*}{ Analytes } & \multicolumn{2}{|c|}{ Fillet } & \multicolumn{2}{|c|}{ Carcass } & \multicolumn{2}{|c|}{ Viscera } \\
\hline & $\begin{array}{c}\text { LOD } \\
\left(\mathbf{n g} / \mathbf{g}_{\mathrm{ww}}\right)\end{array}$ & $\begin{array}{c}\text { LOQ } \\
\left(\mathrm{ng} / \mathbf{g}_{\mathrm{ww}}\right)\end{array}$ & $\begin{array}{c}\text { LOD } \\
\left(\mathrm{ng} / \mathrm{g}_{\mathrm{ww}}\right)\end{array}$ & $\begin{array}{c}\text { LOQ } \\
\left(\mathrm{ng} / \mathrm{g}_{\mathrm{ww}}\right)\end{array}$ & $\begin{array}{c}\text { LOD } \\
\left(\mathbf{n g} / \mathbf{g}_{\mathrm{ww}}\right)\end{array}$ & $\begin{array}{c}\text { LOQ } \\
\left(\mathrm{ng} / \mathrm{g}_{\mathrm{ww}}\right)\end{array}$ \\
\hline PFHxA & 0.01 & 0.04 & 0.02 & 0.08 & 0.04 & 0.13 \\
\hline PFHpA & 0.02 & 0.08 & 0.04 & 0.16 & 0.07 & 0.27 \\
\hline PFOA & 0.02 & 0.08 & 0.04 & 0.16 & 0.07 & 0.27 \\
\hline PFNA & 0.01 & 0.04 & 0.03 & 0.08 & 0.05 & 0.13 \\
\hline PFDA & 0.01 & 0.04 & 0.03 & 0.08 & 0.05 & 0.13 \\
\hline PFUnDA & 0.01 & 0.02 & 0.02 & 0.04 & 0.03 & 0.07 \\
\hline PFDoDA & 0.01 & 0.02 & 0.01 & 0.04 & 0.02 & 0.07 \\
\hline PFTrDA & 0.01 & 0.04 & 0.03 & 0.08 & 0.05 & 0.13 \\
\hline PFTeDA & 0.01 & 0.04 & 0.02 & 0.08 & 0.03 & 0.13 \\
\hline PFHxS & 0.02 & 0.04 & 0.04 & 0.08 & 0.07 & 0.13 \\
\hline PFOS & 0.04 & 0.10 & 0.08 & 0.20 & 0.13 & 0.33 \\
\hline
\end{tabular}

Table S6: Degurba data and Degurba index for the different catchment lakes. Degurba Index (DUI) is defined as: DUI $=5^{*}(\%$ Class 1$)+(\%$ Class 2$)$. DEGURBA data have been obtained by EUROSTAT (https://ec.europa.eu/eurostat/web/degree-of-urbanisation/background [April 2019]).

\begin{tabular}{|c|c|c|c|c|}
\hline \multirow{2}{*}{ Basin } & \multicolumn{3}{|c|}{$\begin{array}{l}\text { DEgree of URBAnisation } \\
\text { (DEGURBA) - } 2014\end{array}$} & \multirow[t]{2}{*}{ DUI } \\
\hline & $\begin{array}{l}\text { CLASS } 1 \\
\text { (\% AREA) }\end{array}$ & $\begin{array}{l}\text { CLASS } 2 \\
\text { (\% AREA) }\end{array}$ & $\begin{array}{l}\text { CLASS } 3 \\
\text { (\% AREA) }\end{array}$ & \\
\hline Lake Geneva & 1.76 & 35.49 & 62.74 & 44.29 \\
\hline Lake Maggiore & 2.01 & 21.42 & 76.57 & 31.47 \\
\hline Lake Como & 1.64 & 18.82 & 79.53 & 27.02 \\
\hline Lake Iseo & 0 & 24.20 & 75.80 & 24.20 \\
\hline Lake Garda & 0 & 20.82 & 79.18 & 20.82 \\
\hline Lake Lugano & 13.76 & 42.56 & 43.68 & 111.37 \\
\hline
\end{tabular}


IV. Results

Table S7. Characteristics of the samples prepared for PFAS analysis. Average \pm standard deviation, in brackets the number of samples.

\begin{tabular}{|c|c|c|c|c|c|c|c|c|c|}
\hline & & $\begin{array}{c}\text { Shad } \\
\text { (Alosa agone) }\end{array}$ & $\begin{array}{c}\text { European } \\
\text { whitefish } \\
\text { (Coregonus } \\
\text { lavaretus) }\end{array}$ & $\begin{array}{c}\text { Burbot } \\
\text { (Lota lota) }\end{array}$ & $\begin{array}{c}\text { Rainbow trout } \\
\text { (Oncorhynchus } \\
\text { mykiss) }\end{array}$ & $\begin{array}{c}\text { European perch } \\
\text { (Perca } \\
\text { fluviatilis) }\end{array}$ & $\begin{array}{c}\text { Roach } \\
\text { (Rutilus rutilus) }\end{array}$ & $\begin{array}{l}\text { Brown } \\
\text { trout } \\
\text { (Salmo } \\
\text { trutta) }\end{array}$ & $\begin{array}{l}\text { Arctic char } \\
\text { (Salvelinus } \\
\text { alpinus) }\end{array}$ \\
\hline Length (cm) & & $27.3 \pm 5.2(44)$ & n.d & $27.9 \pm 3.2(7)$ & $17.5(2)$ & $22.2 \pm 3.0(15)$ & $23.1 \pm 4.6(10)$ & $28.7(1)$ & $16.7 \pm 3.1(2)$ \\
\hline Weight (g) & & $194.1 \pm 141.3(43)$ & n.d. & $160.2 \pm 62.3(7)$ & $69.3(2)$ & $182.9 \pm 89.1(12)$ & $163.2 \pm 130.6(7)$ & $193.7(1)$ & $56.1 \pm 25.2(2)$ \\
\hline \multirow{3}{*}{$\begin{array}{l}\text { \% of body } \\
\text { weight } \\
\left(\mathrm{g} / 100 \mathrm{~g}_{\mathrm{ww}}\right)\end{array}$} & $\mathbf{F}$ & $32 \pm 6(26)$ & & $39 \pm 5(7)$ & & & $39 \pm 10(7)$ & $41(1)$ & \\
\hline & $\mathbf{v}$ & $13 \pm 2(26)$ & & $14 \pm 3(7)$ & & & $13 \pm 1(7)$ & $9(1)$ & \\
\hline & C & $55 \pm 7(26)$ & & $47 \pm 6(7)$ & & & $48 \pm 11(7)$ & $50(1)$ & \\
\hline \multirow{4}{*}{$\begin{array}{l}\text { Dry mass } \\
\text { fraction - } \\
\text { fdw }\left(g / g_{w w}\right)\end{array}$} & $\mathbf{F}$ & $0.27 \pm 0.04(42)$ & $0.19 \pm 0.05(4)$ & $0.22 \pm 0.03(8)$ & $0.22 \pm 0.01(2)$ & $0.21 \pm 0.04$ (17) & $0.21 \pm 0.03(14)$ & $0.17(1)$ & $0.20 \pm 0.04(3)$ \\
\hline & $\mathbf{V}$ & $0.32 \pm 0.10(23)$ & & $0.34 \pm 0.03(7)$ & & & $0.46 \pm 0.10(7)$ & $0.19(1)$ & \\
\hline & C & $0.34 \pm 0.04(22)$ & & $0.25 \pm 0.03(7)$ & & & $0.34 \pm 0.03(7)$ & $0.27(1)$ & \\
\hline & WB & $0.30 \pm 0.05(22)$ & & $0.25 \pm 0.01(7)$ & & & $0.32 \pm 0.03(7)$ & $0.22(1)$ & \\
\hline \multirow{4}{*}{$\begin{array}{l}\text { Lipid } \\
\text { fraction - } \\
\text { fLip (g/gww) }\end{array}$} & $\mathbf{F}$ & $0.06 \pm 0.03(29)$ & $0.02 \pm 0.02(3)$ & $0.01(1)$ & & $0.01 \pm 0.003(14)$ & $0.01 \pm 0.002(4)$ & $0.03(1)$ & $0.01(1)$ \\
\hline & $\mathbf{V}$ & $0.10 \pm 0.10(6)$ & & & & & & $0.04(1)$ & \\
\hline & C & $0.12 \pm 0.03(6)$ & & & & & & $0.04(1)$ & \\
\hline & WB & $0.09 \pm 0.03(5)$ & & & & & & $0.03(1)$ & \\
\hline \multirow{4}{*}{$\begin{array}{l}\text { Polar Lipid } \\
\text { fraction - fLP } \\
\left(\mathrm{g} / \mathrm{g}_{\mathrm{ww}}\right)\end{array}$} & $\mathbf{F}$ & $0.20 \pm 0.11(3)$ & & & & & & $0.28(1)$ & \\
\hline & $\mathbf{v}$ & $0.41 \pm 0.13(3)$ & & & & & & $0.30(1)$ & \\
\hline & C & $0.21 \pm 0.12(3)$ & & & & & & $0.14(1)$ & \\
\hline & WB & $0.24 \pm 0.10(3)$ & & & & & & $0.21(1)$ & \\
\hline & $\mathbf{F}$ & $0.04 \pm 0.01(3)$ & & & & & & $0.02(1)$ & \\
\hline
\end{tabular}


Neutral Lipid V $\quad 0.03 \pm 0.02(3)$

fraction - C $0.11 \pm 0.02(3)$

0.02 (1)

0.04 (1)

$\mathrm{fLN}\left(\mathrm{g} / \mathrm{g}_{\mathrm{ww}}\right) \quad$ WB $\quad 0.07 \pm 01(3)$

$0.03(1)$

Protein

F $\quad 0.07 \pm 0.02(9)$

0.07 (1)

$0.08 \pm 0.02(6)$

0.09 (1)

0.07 (1)

$0.07 \pm 0.02(5)$

0.07 (1) 
Table S8. PFAS concentrations, dry weight and lipid and protein content in fillet samples $\left(\mathrm{ng} / \mathrm{g}_{\mathrm{ww}}\right)$ (see excel file). n.d. not determined

Table S9. PFAS concentrations, dry weight and lipid and protein content in viscera samples $\left(\mathrm{ng} / \mathrm{g}_{\mathrm{ww}}\right)$ (see excel file). n.d. not determined

Table S10. PFAS concentrations, dry weight and lipid and protein content in carcass samples $\left(\mathrm{ng} / \mathrm{g}_{\mathrm{ww}}\right)$ (see excel file). n.d. not determined

Table S11. PFAS concentrations, dry weight and lipid and protein content in whole-body samples $\left(\mathrm{ng} / \mathrm{g}_{\mathrm{ww}}\right)$ (see excel file). n.d. not determined 
Table S12. Ratios between PFOS and $\sum$ LC-PFAS concentrations in the different tissues. Concentrations in ng/gww. In the calculation of $\sum$ LC-PFAS, value $<$ LOD have been set as zero.

\begin{tabular}{|c|c|c|c|c|c|c|c|c|c|c|c|c|c|}
\hline & & \multicolumn{3}{|c|}{ Fillet } & \multicolumn{3}{|c|}{ Liver } & \multicolumn{3}{|c|}{ Viscera } & \multicolumn{3}{|c|}{ Carcass } \\
\hline & & PFOS & $\sum$ LC-PFCA & $\begin{array}{c}\text { Ratio } \\
\text { PFOS/ } \\
\text { \&LC-PFCA } \\
\end{array}$ & PFOS & $\sum$ LC-PFCA & $\begin{array}{c}\text { Ratio } \\
\text { PFOS/ } \\
\text { \&LC-PFCA } \\
\end{array}$ & PFOS & $\sum$ LC-PFCA & $\begin{array}{c}\text { Ratio } \\
\text { PFOS/ } \\
\text { ¿LC-PFCA } \\
\end{array}$ & PFOS & $\sum$ LC-PFCA & $\begin{array}{c}\text { Ratio } \\
\text { PFOS/ } \\
\text { \&LC-PFCA } \\
\end{array}$ \\
\hline \multirow{2}{*}{$\begin{array}{l}\text { Lake } \\
\text { Maggiore }\end{array}$} & Median & 8.58 & 0.64 & 15.12 & & & & 52.49 & 6.34 & 8.04 & 18.86 & 2.70 & 8.28 \\
\hline & Min-Max & $3.72-19.85$ & $0.12-1.97$ & $4.42-34.38$ & & & & $\begin{array}{c}34.84- \\
57.84\end{array}$ & $2.61-6.97$ & $5.29-22.19$ & $\begin{array}{l}18.40- \\
22.28\end{array}$ & $0.93-3.55$ & $5.21-19.85$ \\
\hline \multirow{2}{*}{ Lake Garda } & Median & 1.36 & 0.36 & 7.04 & & & & 15.17 & 3.11 & 4.76 & 4.26 & 1.13 & 3.76 \\
\hline & Min-Max & $0.65-4.82$ & $0.06-0.49$ & $2.90-21.31$ & & & & 5.79-31.49 & $1.85-6.77$ & $1.93-10.13$ & $3.59-6.72$ & $0.84-2.75$ & $2.08-5.42$ \\
\hline \multirow{2}{*}{ Lake Como } & Median & 4.08 & 0.45 & 6.46 & & & & 30.04 & 4.92 & 6.44 & 12.00 & 1.98 & 5.97 \\
\hline & Min-Max & $1.62-5.97$ & $0.08-1.62$ & $1.87-27.36$ & & & & $\begin{array}{l}14.52- \\
77.01 \\
\end{array}$ & $1.91-13.71$ & $2.02-16.44$ & $6.90-30.21$ & $1.23-4.84$ & $2.65-9.69$ \\
\hline \multirow{2}{*}{$\begin{array}{l}\text { Lake } \\
\text { Geneva }\end{array}$} & Median & 9.13 & 2.16 & 5.26 & 20.20 & 3.34 & 4.87 & 28.33 & 5.46 & 5.89 & 22.61 & 5.85 & 5.19 \\
\hline & Min-Max & $2.43-19.31$ & $0.24-3.85$ & $2.00-10.30$ & $9.38-57.84$ & $2.09-14.44$ & $2.70-12.00$ & $8.65-55.17$ & $0.94-13.14$ & $2.11-10.65$ & $6.74-55.23$ & 0.93-11.69 & $1.76-7.95$ \\
\hline Lake Iseo & Min-Max & $0.42-2.52$ & $0.08-0.96$ & $0.74-11.54$ & & & & $3.61-15.06$ & $1.03-11.51$ & $0.75-14.58$ & $2.11-3.15$ & $0.42-4.64$ & $0.56-7.02$ \\
\hline \multirow{2}{*}{$\begin{array}{l}\text { Lake Lugano } \\
\text { (Solcà 2016, } \\
\text { and present } \\
\text { study) }\end{array}$} & Median & 15.74 & 4.16 & 2.90 & & & & & & & & & \\
\hline & Min-Max & $3.71-50.46$ & $0.74-16.82$ & $1.56-15.98$ & & & & & & & & & \\
\hline \multirow{2}{*}{$\begin{array}{l}\text { Lake } \\
\text { Varese }\end{array}$} & Median & 6.97 & 3.25 & 2.09 & & & & & & & & & \\
\hline & Min-Max & $2.07-12.48$ & $0.84-7.60$ & $1.52-2.48$ & & & & & & & & & \\
\hline \multirow{2}{*}{$\begin{array}{l}\text { Lake } \\
\text { Mergozzo }\end{array}$} & Median & 5.37 & 3.12 & 1.94 & & & & & & & & & \\
\hline & Min-Max & $0.27-38.40$ & $0.09-21.77$ & $0.95-3.32$ & & & & & & & & & \\
\hline \multirow{2}{*}{$\begin{array}{l}\text { Lakes } \\
\text { Sassolo } \\
\text { (Steingruber } \\
\text { 2018). }\end{array}$} & Median & 0.32 & 0.44 & 0.68 & & & & & & & & & \\
\hline & Min-Max & $0.20-0.83$ & $0-02-1.95$ & $0.43-9.46$ & & & & & & & & & \\
\hline
\end{tabular}





\section{Discussions}

Table S13 Main descriptive parameters of the carcass-to-viscera and fillet-to-viscera ratios of concentrations normalised to fresh weight and dry weight for the same fish samples

\begin{tabular}{|c|c|c|c|c|c|c|c|c|c|c|c|}
\hline & & $\begin{array}{l}\text { PFOS } \\
\text { (based } \\
\text { on } \mathrm{fw} \text { ) }\end{array}$ & $\begin{array}{l}\text { PFOS } \\
\text { (based } \\
\text { on dw) }\end{array}$ & $\begin{array}{l}\text { PFNA } \\
\text { (based } \\
\text { on } \mathrm{fw} \text { ) }\end{array}$ & $\begin{array}{l}\text { PFNA } \\
\text { (based } \\
\text { on dw) }\end{array}$ & $\begin{array}{l}\text { PFDA } \\
\text { (based } \\
\text { on } \mathrm{fw} \text { ) }\end{array}$ & $\begin{array}{l}\text { PFDA } \\
\text { (based } \\
\text { on dw) }\end{array}$ & $\begin{array}{l}\text { PFUnDA } \\
\text { (based } \\
\text { on } \mathrm{fw} \text { ) }\end{array}$ & $\begin{array}{c}\text { PFUnDA } \\
\text { (based } \\
\text { on dw) }\end{array}$ & $\begin{array}{l}\text { PFDoDA } \\
\text { (based } \\
\text { on } \mathrm{fw} \text { ) }\end{array}$ & $\begin{array}{l}\text { PFDoDA } \\
\text { (based } \\
\text { on dw) }\end{array}$ \\
\hline \multirow[t]{5}{*}{ Carcass/Viscera } & $\mathrm{N}$ & 30 & 30 & 21 & 21 & 30 & 30 & 29 & 29 & 29 & 29 \\
\hline & median & 0.55 & 0.53 & 0.53 & 0.46 & 0.59 & 0.61 & 0.74 & 0.70 & 0.64 & 0.51 \\
\hline & mean & 0.62 & 0.75 & 1.37 & 1.79 & 0.71 & 0.89 & 0.77 & 0.97 & 0.70 & 0.89 \\
\hline & SD & 0.35 & 0.56 & 2.26 & 3.22 & 0.41 & 0.67 & 0.44 & 0.71 & 0.46 & 0.73 \\
\hline & RSD & 56 & 75 & 165 & 180 & 57 & 76 & 56 & 74 & 65 & 82 \\
\hline \multirow[t]{5}{*}{ Fillet/Viscera } & $\mathrm{N}$ & 30 & 30 & 21 & 21 & 30 & 30 & 29 & 29 & 29 & 29 \\
\hline & median & 0.20 & 0.28 & 0.16 & 0.24 & 0.17 & 0.26 & 0.19 & 0.29 & 0.25 & 0.26 \\
\hline & mean & 0.23 & 0.38 & 0.57 & 0.92 & 0.24 & 0.41 & 0.25 & 0.42 & 0.25 & 0.43 \\
\hline & SD & 0.15 & 0.29 & 0.97 & 1.62 & 0.19 & 0.36 & 0.20 & 0.37 & 0.20 & 0.38 \\
\hline & RSD & 64 & 78 & 171 & 176 & 78 & 88 & 83 & 89 & 79 & 88 \\
\hline
\end{tabular}

Table S14 Main descriptive parameters of the carcass-to-viscera and fillet-to-viscera ratios of concentrations normalised to fresh weight and polar lipid content for the same fish samples

\begin{tabular}{|l|l|c|c|c|c|c|c|c|c|c|c|}
\hline & & $\begin{array}{l}\text { PFOS } \\
\text { (based } \\
\text { on fw) }\end{array}$ & $\begin{array}{c}\text { PFOS } \\
\text { (based } \\
\text { on LP) }\end{array}$ & $\begin{array}{l}\text { PFNA } \\
\text { (based } \\
\text { on fw) }\end{array}$ & $\begin{array}{c}\text { PFNA } \\
\text { (based } \\
\text { on LP) }\end{array}$ & $\begin{array}{l}\text { PFDA } \\
\text { (based } \\
\text { on fw) }\end{array}$ & $\begin{array}{c}\text { PFDA } \\
\text { (based } \\
\text { on LP) }\end{array}$ & $\begin{array}{l}\text { PFUnDA } \\
\text { (based } \\
\text { on fw) }\end{array}$ & $\begin{array}{c}\text { PFUnDA } \\
\text { (based } \\
\text { on LP) }\end{array}$ & $\begin{array}{l}\text { PFDoDA } \\
\text { (based } \\
\text { on fw) }\end{array}$ & $\begin{array}{c}\text { PFDoDA } \\
\text { (based } \\
\text { on LP) }\end{array}$ \\
\hline Carcass/Viscera & N & $\mathbf{4}$ & 4 & $\mathbf{4}$ & 4 & $\mathbf{4}$ & 4 & $\mathbf{2}$ & 2 & $\mathbf{2}$ & 2 \\
\hline & median & $\mathbf{0 . 3 6}$ & 0.59 & $\mathbf{0 . 3 0}$ & 0.79 & $\mathbf{0 . 3 1}$ & 0.61 & & & & \\
\hline & mean & $\mathbf{0 . 3 6}$ & 0.85 & $\mathbf{0 . 3 8}$ & 0.77 & $\mathbf{0 . 4 0}$ & 0.65 & $\mathbf{0 . 6 4}$ & 1.02 & $\mathbf{0 . 6 4}$ & 1.04 \\
\hline & SD & $\mathbf{0 . 1 6}$ & 0.68 & $\mathbf{0 . 2 6}$ & 0.42 & $\mathbf{0 . 4 2}$ & 0.56 & $\mathbf{0 . 3 0}$ & 0.19 & $\mathbf{0 . 2 2}$ & 0.05 \\
\hline & RSD & $\mathbf{4 3}$ & 80 & $\mathbf{6 8}$ & 54 & $\mathbf{1 0 5}$ & 87 & $\mathbf{4 7}$ & 18 & $\mathbf{3 4}$ & 4 \\
\hline & & & & & & & & & & & \\
\hline Fillet/Viscera & $\mathrm{N}$ & $\mathbf{4}$ & 4 & $\mathbf{4}$ & 4 & $\mathbf{4}$ & 4 & $\mathbf{3}$ & 3 & $\mathbf{3}$ & 3 \\
\hline
\end{tabular}




\begin{tabular}{|l|l|c|c|c|c|c|c|c|c|c|c|}
\hline & median & $\mathbf{0 . 1 4}$ & 0.22 & $\mathbf{0 . 2 3}$ & 0.35 & $\mathbf{0 . 1 5}$ & 0.23 & $\mathbf{0 . 1 4}$ & 0.21 & $\mathbf{0 . 1 4}$ & 0.21 \\
\hline & mean & $\mathbf{0 . 1 4}$ & 0.34 & $\mathbf{0 . 2 2}$ & 0.57 & $\mathbf{0 . 2 4}$ & 0.70 & $\mathbf{0 . 2 1}$ & 0.65 & $\mathbf{0 . 2 4}$ & 0.78 \\
\hline & SD & $\mathbf{0 . 0 6}$ & 0.34 & $\mathbf{0 . 1 3}$ & 0.63 & $\mathbf{0 . 2 1}$ & 1.01 & $\mathbf{0 . 1 8}$ & 0.88 & $\mathbf{0 . 2 3}$ & 1.09 \\
\hline & RSD & $\mathbf{4 1}$ & 101 & $\mathbf{6 0}$ & 112 & $\mathbf{8 7}$ & 146 & $\mathbf{8 8}$ & 136 & $\mathbf{9 2}$ & 139 \\
\hline
\end{tabular}


Table S15 Literature data on European Lakes. Data are expressed in $\mathrm{ng} / \mathrm{g}_{\mathrm{ww}}$.

\begin{tabular}{|c|c|c|c|c|c|c|c|c|c|c|c|c|c|c|}
\hline & & PFHxA & PFHpA & PFOA & PFNA & PFDA & PFUnDA & PFDoDA & PFTrDA & PFTeDA & PFHxS & PFOS & ¿PFAS & $\begin{array}{c}\text { Ratio } \\
\text { PFOS/ } \\
\text { ¿LC-PFCA }\end{array}$ \\
\hline \multicolumn{15}{|c|}{ Fillet } \\
\hline \multirow{4}{*}{$\begin{array}{l}\text { Lakes } \\
\text { Maggiore } \\
\text { and Varese } \\
\text { (Italy) }\end{array}$} & Mean & & & 0.2 & & & & & & & & 17 & & \\
\hline & Median & & & $<L O D$ & & & & & & & & 19.1 & & \\
\hline & Min-Max & & & $<$ LOD-0.5 & & & & & & & & $9.6-22.4$ & & \\
\hline & \multicolumn{14}{|c|}{ Reference: (Squadrone 2014; Squadrone 2015) Species: Coregonus lavaretus; Perca fluviatilis } \\
\hline \multirow{4}{*}{$\begin{array}{l}\text { Lake Garda } \\
\text { (Italy) }\end{array}$} & Mean & & 0.1 & 0.2 & 0.4 & 0.9 & 0.6 & 0.9 & 0.4 & 1.7 & & 2.2 & & 0.4 \\
\hline & Median & & $<\mathrm{LOD}$ & 0.2 & 0.3 & 0.6 & $<L O D$ & 0.02 & $<\mathrm{LOD}$ & $<$ LOD & & 1.7 & & 0.7 \\
\hline & Min-Max & & $<$ LOD-0.1 & $<$ LOD- 0.5 & $<$ LOD-1.5 & $<$ LOD-4.4 & $<$ LOD-1.8 & $<$ LOD-5.4 & $<$ LOD-1.5 & $<$ LOD-10 & & $<$ LOD-7.8 & & \\
\hline & \multicolumn{14}{|c|}{ Reference: (Chiesa 2018) Species: Anguilla anguilla } \\
\hline \multirow{4}{*}{$\begin{array}{l}\text { Northern } \\
\text { German } \\
\text { lakes }\end{array}$} & Mean & & & $<$ LOD & & & & & & & & 57.6 & & \\
\hline & Median & & & $\angle L O D$ & & & & & & & & 66 & & \\
\hline & Min-Max & & & $\angle L O D$ & & & & & & & & $<$ LOD-225.4 & & \\
\hline & \multicolumn{14}{|c|}{ Reference: (Schuetze 2010) Species A. anguilla; Cyprinus carpio; trout } \\
\hline \multirow{4}{*}{$\begin{array}{l}\text { Lake Mohne } \\
\text { (Germany) }\end{array}$} & Mean & & & & & & & & & & & 46.9 & & \\
\hline & Median & & & & & & & & & & & 46.4 & & \\
\hline & Min-Max & & & & & & & & & & & 6.4-83.4 & & \\
\hline & \multicolumn{14}{|c|}{ Reference: (Holzer 2011) A. anguilla; C. lavaretus; Esox lucius; P. fluviatilis; Rutilus rutilus } \\
\hline \multirow[t]{4}{*}{ Dutch lakes } & Mean & $<$ LOD & & $<\mathrm{LOD}$ & 1.5 & 7.8 & 8.7 & 8.4 & 2.8 & 0.8 & 0.03 & 23.7 & 53.7 & 1.1 \\
\hline & Median & $<L O D$ & & $<L O D$ & 1 & 7.6 & 8.2 & 8.1 & 2.7 & 0.2 & $<L O D$ & 24.6 & 49.9 & 0.9 \\
\hline & Min-Max & $\angle L O D$ & & $<$ LOD & $<$ LOD-4.7 & $6.0-10.3$ & 13.9 & $3.5-17.7$ & $1.7-4.8$ & $<$ LOD-3.7 & $<$ LOD-0.2 & $14.8-30.2$ & $44.5-69.6$ & $0.5-2.1$ \\
\hline & \multicolumn{14}{|c|}{ Reference: (Zafeiraki 2019) Species: A. anguilla } \\
\hline \multirow{4}{*}{$\begin{array}{l}\text { Lake } \\
\text { Vättern } \\
\text { (Sweden) }\end{array}$} & Mean & & & 0.1 & 0.3 & 0.4 & 0.4 & 0.2 & 0.9 & 0.2 & 0.2 & 8.1 & 10.8 & 6.1 \\
\hline & Median & & & 0.1 & 0.2 & 0.4 & 0.4 & 0.3 & 1.0 & 0.2 & 0.1 & 8.5 & 11.7 & 5.7 \\
\hline & Min-Max & & & $<L O D-0.3$ & $0.2-0.7$ & $0.3-0.6$ & $0.2-0.6$ & $<$ LOD-0.3 & $0.2-1.4$ & $<$ LOD-0.5 & $0.03-0.7$ & $2.9-12$ & 4-16.4 & $3.2-8.4$ \\
\hline & \multicolumn{14}{|c|}{ Reference: (Berger 2009) Species: C. lavaretus; Lota lota; P. fluviatilis; Salmo salar; Salmo trutta } \\
\hline \multirow{5}{*}{$\begin{array}{l}\text { Swedish } \\
\text { lakes }\end{array}$} & Mean & $<$ LOD & & $<\mathrm{LOD}$ & & & & & & & 0.2 & 41.4 & 41.6 & \\
\hline & Median & $<L O D$ & & $<L O D$ & & & & & & & $<\mathrm{LOD}$ & 21.4 & 21.4 & \\
\hline & Min-Max & $<L O D$ & & $<L O D$ & & & & & & & $<$ LOD-0.85 & $0.7-370$ & $0.7-371$ & \\
\hline & \multicolumn{14}{|c|}{ Reference: (Filipovic 2015) Species: Abramis brama; E. lucius; Gymnocephalus cernuus; R. rutilus; $P$. fluviatilis } \\
\hline & & PFHXA & PFHpA & PFOA & PFNA & PFDA & PFUnDA & PFDoDA & PFTrDA & PFTeDA & PFHxS & PFOS & $\sum$ PFAS & $\begin{array}{c}\text { Ratio } \\
\text { PFOS/ } \\
\text { ELC-PFCA } \\
\end{array}$ \\
\hline & & & & & & & (contin & & & & & & & \\
\hline
\end{tabular}




\begin{tabular}{|c|c|c|c|c|c|c|c|c|c|c|c|c|c|}
\hline \multirow{4}{*}{$\begin{array}{l}\text { Lake } \\
\text { Halmsjön } \\
\text { (Sweden) } \\
\text { near airport }\end{array}$} & Mean & & & & & & & & & & 330 & & \\
\hline & Median & & & & & & & & & & & & \\
\hline & Min-Max & & & & & & & & & & $140-520$ & & \\
\hline & \multicolumn{13}{|c|}{ Reference: (Ahrens 2015) Species: P. fluviatilis } \\
\hline \multirow{4}{*}{$\begin{array}{l}\text { Swedish } \\
\text { pristine } \\
\text { lakes }\end{array}$} & Mean & & & & 0.1 & 0.2 & 0.1 & 0.2 & 0.03 & & 0.2 & & 0.5 \\
\hline & Median & & & & & & & & & & & & \\
\hline & Min-Max & & & & $<$ LOD-0.2 & $0.04-0.6$ & $0.01-0.5$ & $0.1-0.9$ & $<$ LOD-0.1 & & $<$ LOD-0.9 & & n.a.- 0.7 \\
\hline & \multicolumn{13}{|c|}{ Reference: (Akerblom 2017) Species: $P$. fluviatilis } \\
\hline \multirow{4}{*}{$\begin{array}{l}\text { Norwegian } \\
\text { lakes }\end{array}$} & Mean & 0.01 & & 0.3 & 0.1 & 1 & 0.02 & 0.1 & 0.01 & 0.2 & 13.1 & 14.8 & 9.1 \\
\hline & Median & $<\mathrm{LOD}$ & & 0.02 & $<\mathrm{LOD}$ & 0.3 & $<\mathrm{LOD}$ & 0.04 & $<\mathrm{LOD}$ & 0.01 & 0.9 & 2 & 7.9 \\
\hline & Min-Max & $<$ LOD-0.1 & & $<$ LOD-2.4 & $<$ LOD-0.5 & $<$ LOD-4.4 & $<$ LOD-0.3 & $<$ LOD-0.8 & $<$ LOD-0.1 & $<$ LOD-2.2 & $<$ LOD-148 & $\begin{array}{l}0.02- \\
155.6 \\
\end{array}$ & n.a.-33.3 \\
\hline & \multicolumn{13}{|c|}{ Reference: (Hansen 2016) Species: Platichthys flesus; S. salar; S. trutta } \\
\hline \multicolumn{14}{|c|}{ Liver } \\
\hline \multirow{4}{*}{$\begin{array}{l}\text { High } \\
\text { mountain } \\
\text { lakes } \\
\text { (France) }\end{array}$} & Mean & & & 1.2 & 5.9 & 11.5 & 7.9 & 4.1 & 2.3 & & 4.2 & 37.1 & 3.5 \\
\hline & Median & & & 0.6 & 5.4 & 9 & 4.4 & 4 & 2.3 & & 4.1 & 33.1 & 0.2 \\
\hline & Min-Max & & & $<$ LOD-3.9 & $<$ LOD-12.2 & $0.2-3$ & $<$ LOD-32 & $0.1-9.3$ & $<$ LOD-6.5 & & $3.1-5.5$ & $4.9-72.2$ & $0.1-27.1$ \\
\hline & \multicolumn{13}{|c|}{ Reference: (Ahrens 2010). Species: Oncorhynchus mykiss; Salvelinus alpinus; Salvelinus namaycush; S. trutta } \\
\hline \multirow{4}{*}{$\begin{array}{l}\text { Faroe } \\
\text { Islands and } \\
\text { Greenland } \\
\text { lakes }\end{array}$} & Mean & & & 0.9 & 0.8 & 3 & 1.4 & 3.7 & 1.1 & & 1.9 & 12.8 & 0.3 \\
\hline & Median & & & 0.8 & 0.7 & 2.4 & 1 & 2.4 & 1.1 & & 1.3 & 9.3 & 0.3 \\
\hline & Min-Max & & & 0.3-1.6 & $0.2-1.9$ & $0.6-6.8$ & $0.5-3$ & $1.5-8.4$ & $0.6-1.7$ & & $0.5-4.7$ & $5.3-27.4$ & $0.2-0.5$ \\
\hline & \multicolumn{13}{|c|}{ Reference: (Bossi 2015) Species: S. alpinus; S. trutta } \\
\hline \multirow{4}{*}{$\begin{array}{l}\text { Lake Belau } \\
\text { (Germany) }\end{array}$} & Mean & & $<\mathrm{LOD}$ & $<$ LOD & 0.4 & 0.6 & $<\mathrm{LOD}$ & $<\mathrm{LOD}$ & & $<\mathrm{LOD}$ & 6.4 & 7.4 & 6.4 \\
\hline & Median & & & & & & & & & & & & \\
\hline & Min-Max & & & & & & & & & & & & \\
\hline & \multicolumn{13}{|c|}{ Reference: (Rudel 2011) Species: $A$. brama } \\
\hline
\end{tabular}



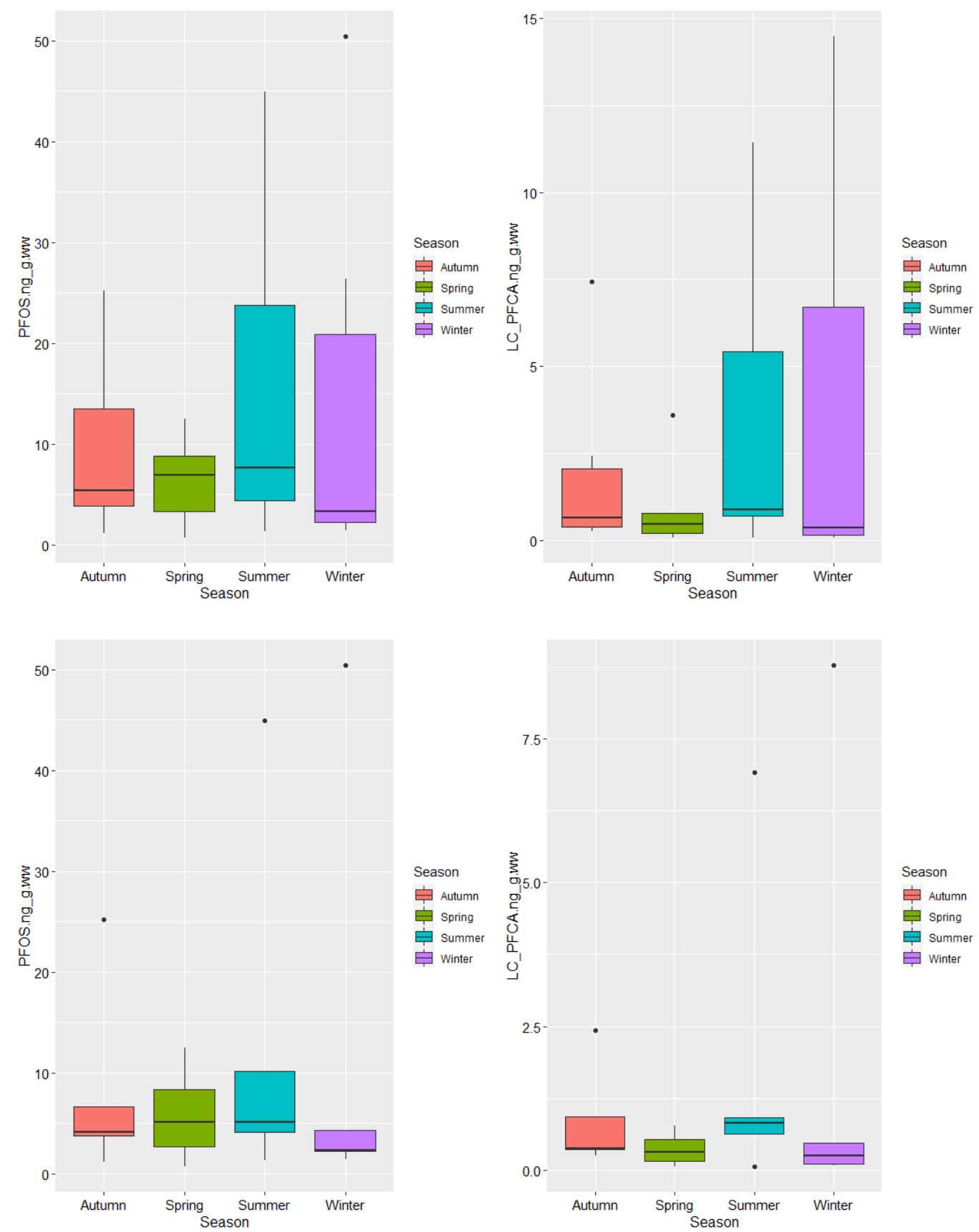

Figure S1 Box-whisker plot of the PFOS and long chain PFCA $\left(\mathrm{C}_{9}-\mathrm{C}_{12}\right)$ fillet concentrations in different seasons (fish sampled in 2018 of Lake Como, Lake Garda, Lake Lugano and Lake Maggiore). Upper plots two species (shad and European perch); lower plot only shad samples. No statistical differences were observed $(\mathrm{p}>0.5)$. 

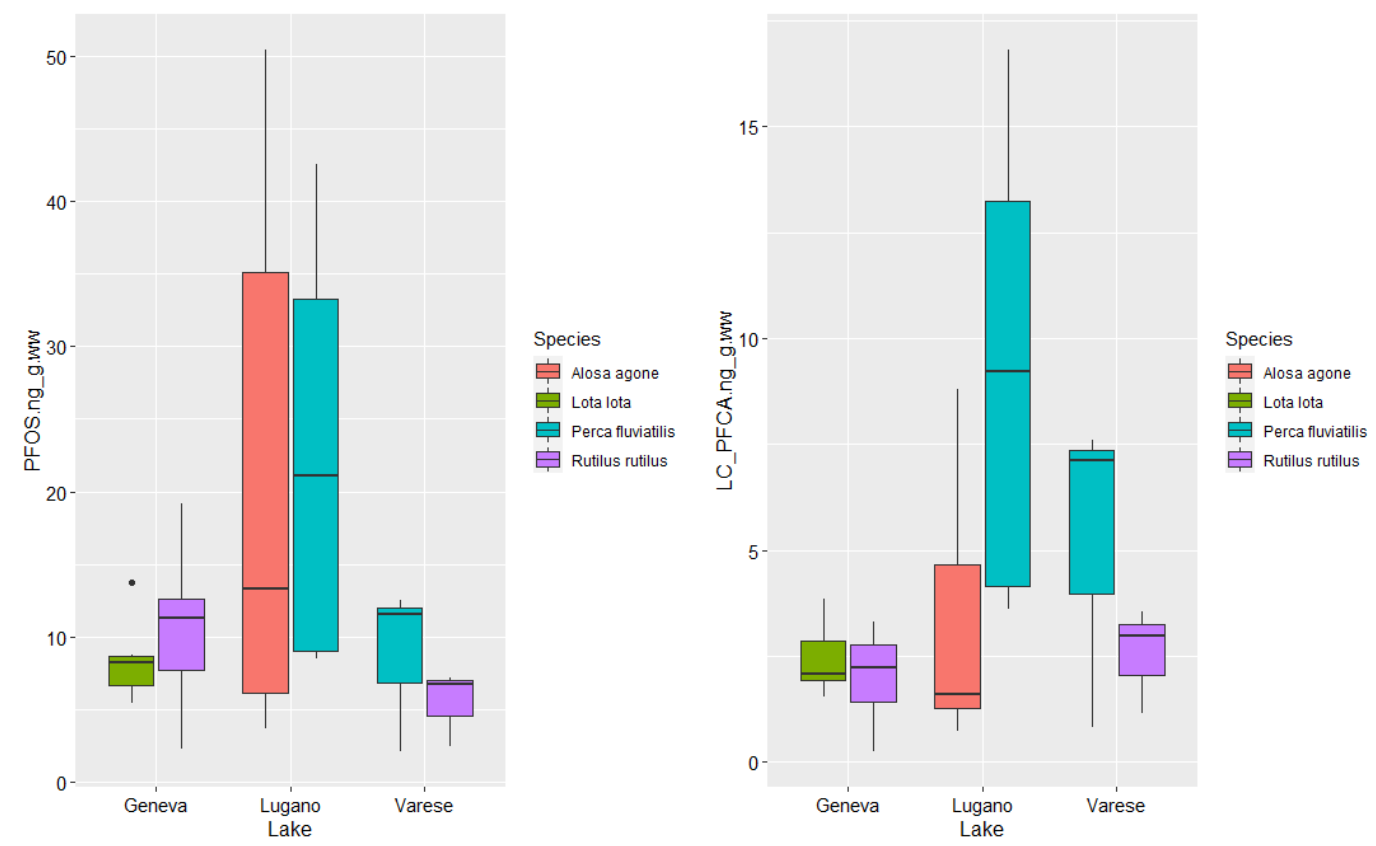

Figure S2 Box-whisker plot of the PFOS and long chain PFCA $\left(\mathrm{C}_{9}-\mathrm{C}_{12}\right)$ fillet concentrations in different lakes by species. No statistical differences were observed $(p>0.5)$. 

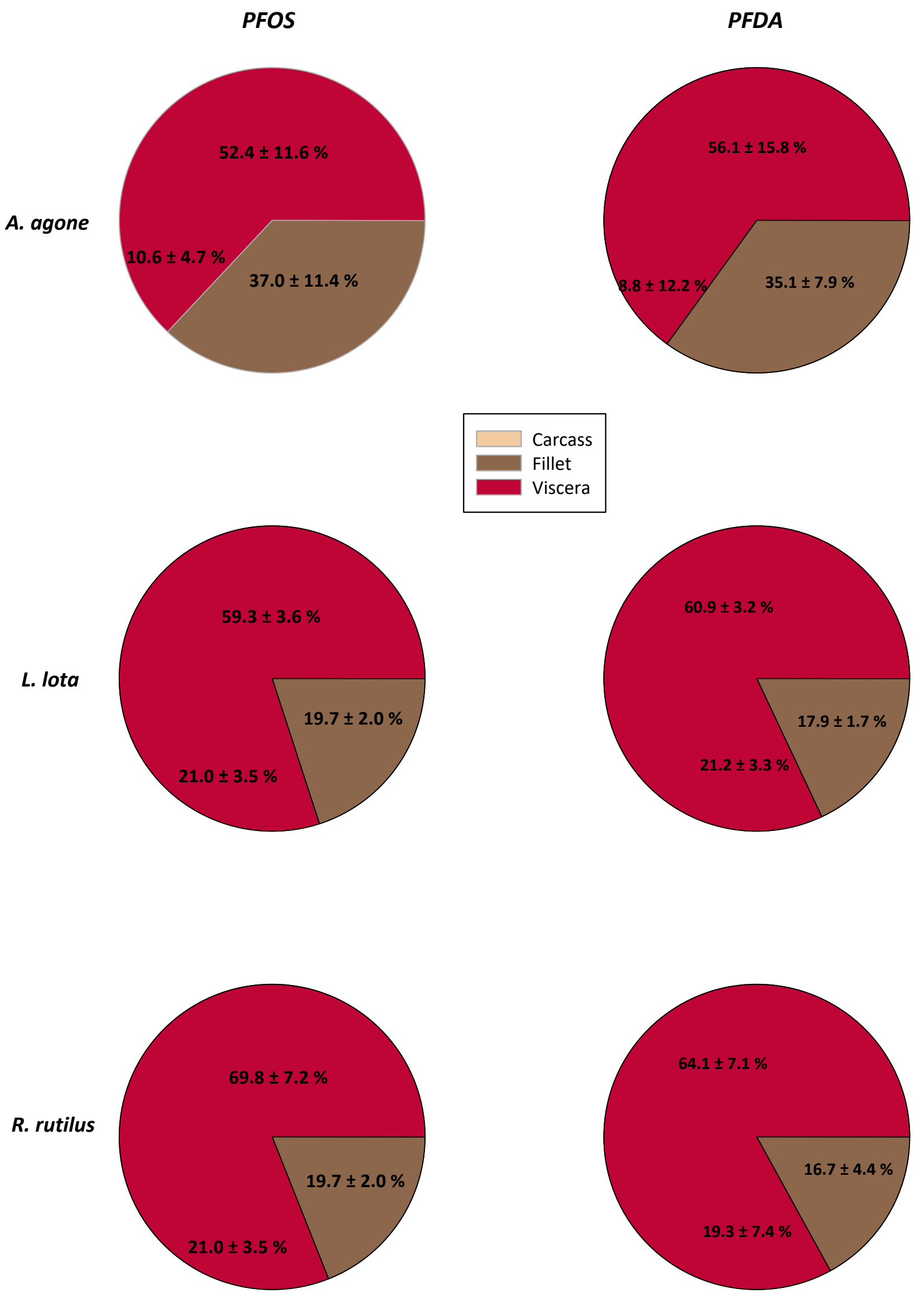

Figure S3 Distribution percentage of PFAS in different fractions of different fish species 

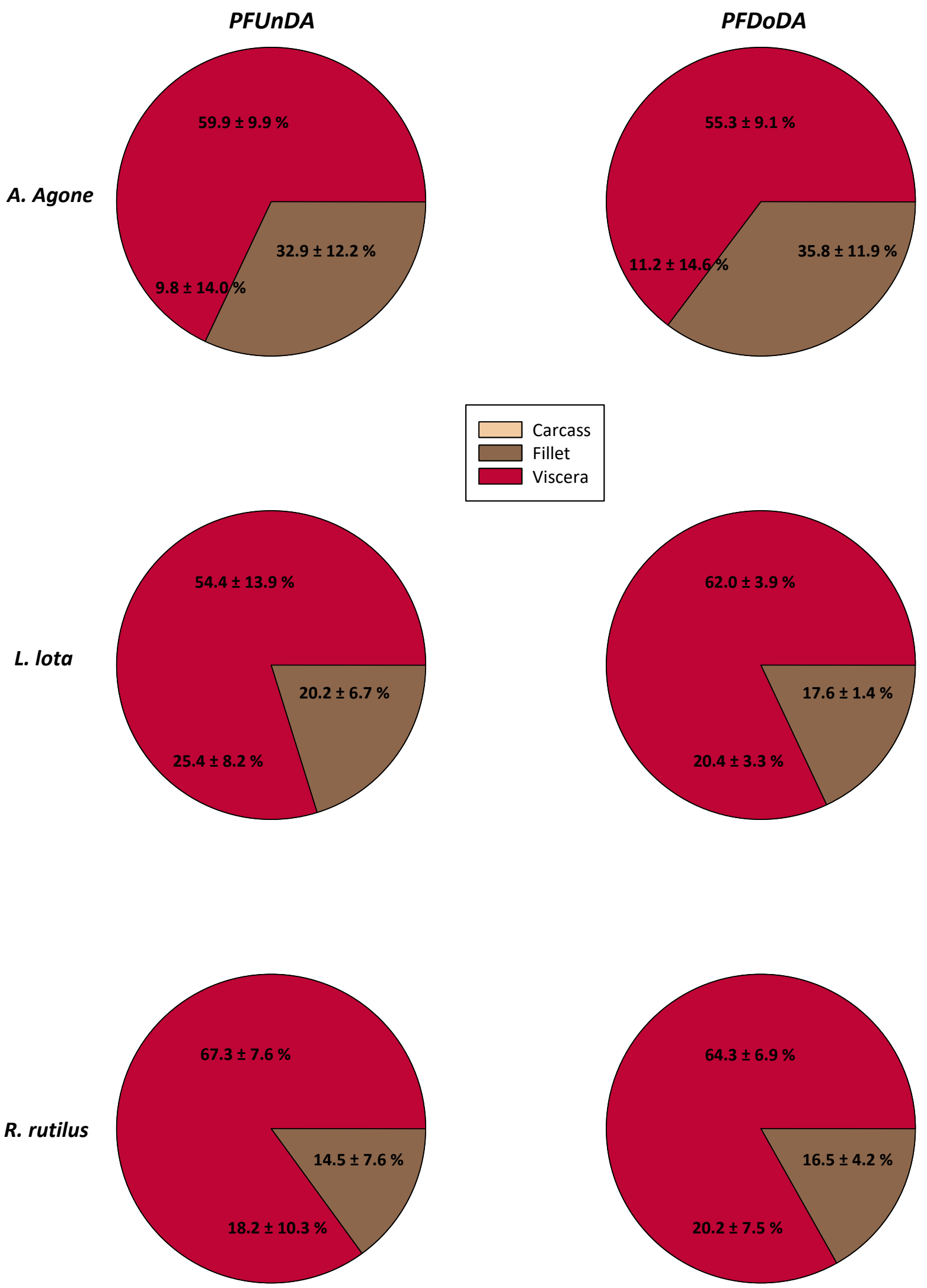

2

3 Figure S3 (continued) Distribution percentage of PFAS in different fractions of different fish 4 species 


$$
5
$$


PFOS

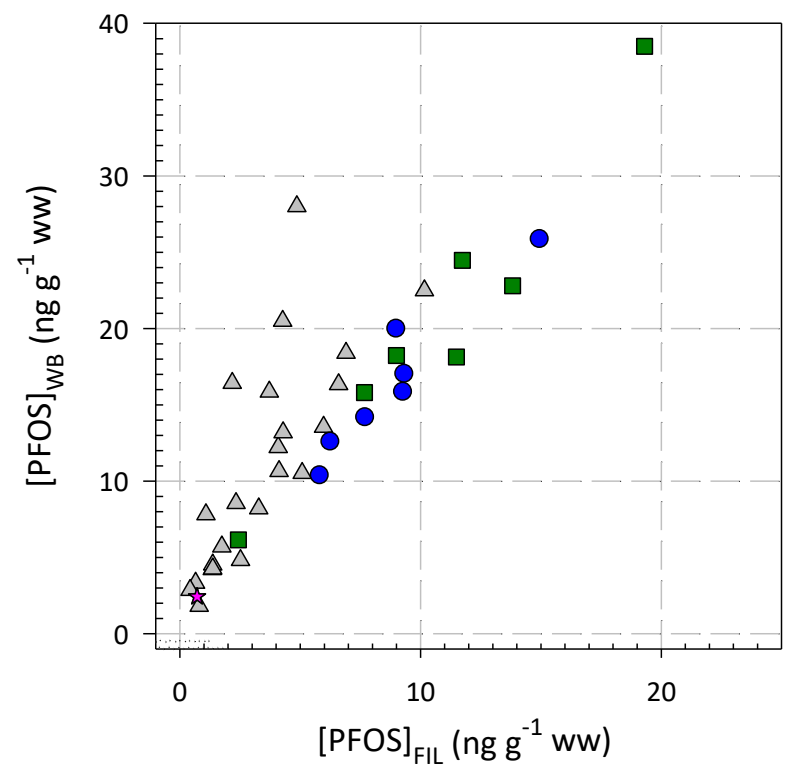

PFUnDA

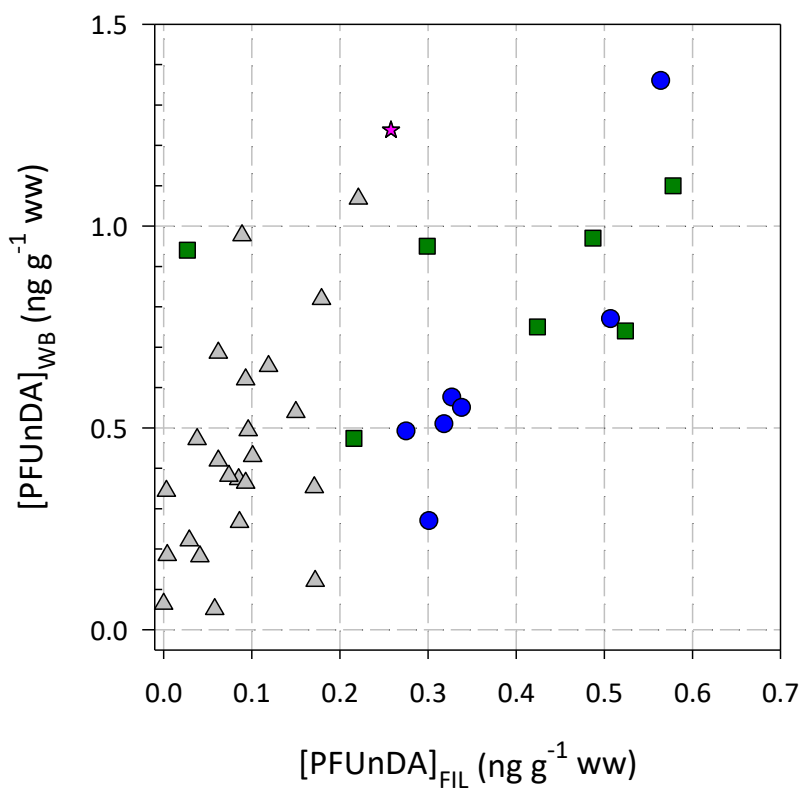

PFDA

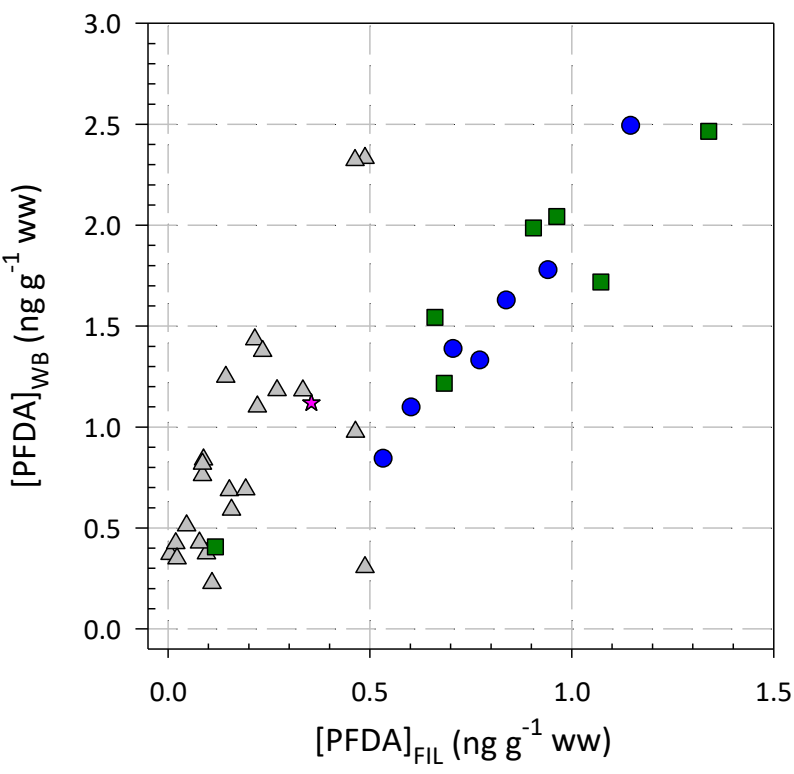

PFDoDA

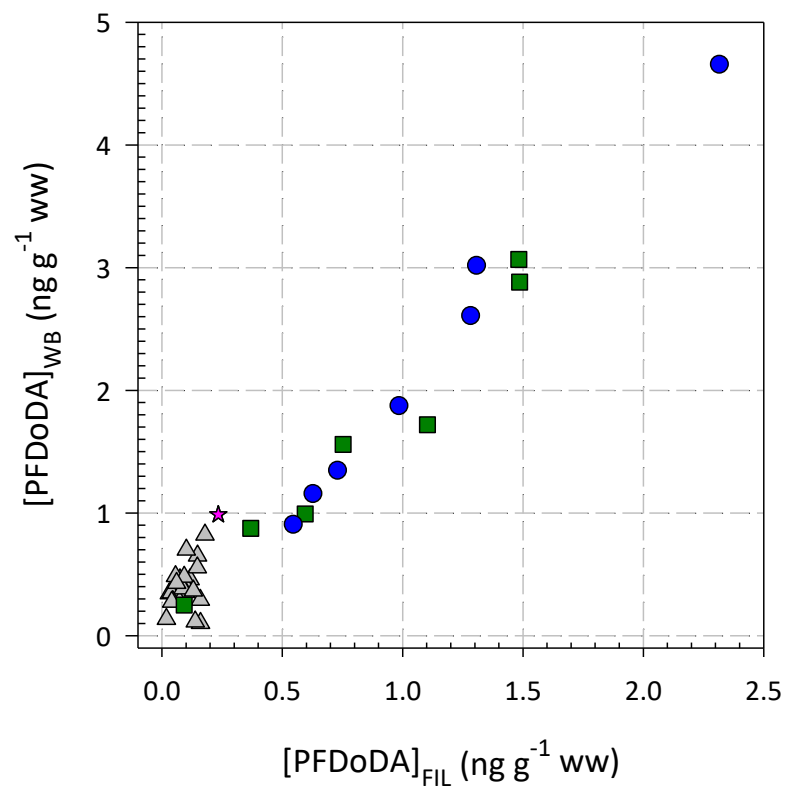

8 Figure S4 Relationship between fillet and whole-body concentrations for PFOS, PFDA,

9 PFUnDA and PFDoDA (grey triangle: shad; pink star: trout; green square: roach; blue dot: 10 burbot)

11 


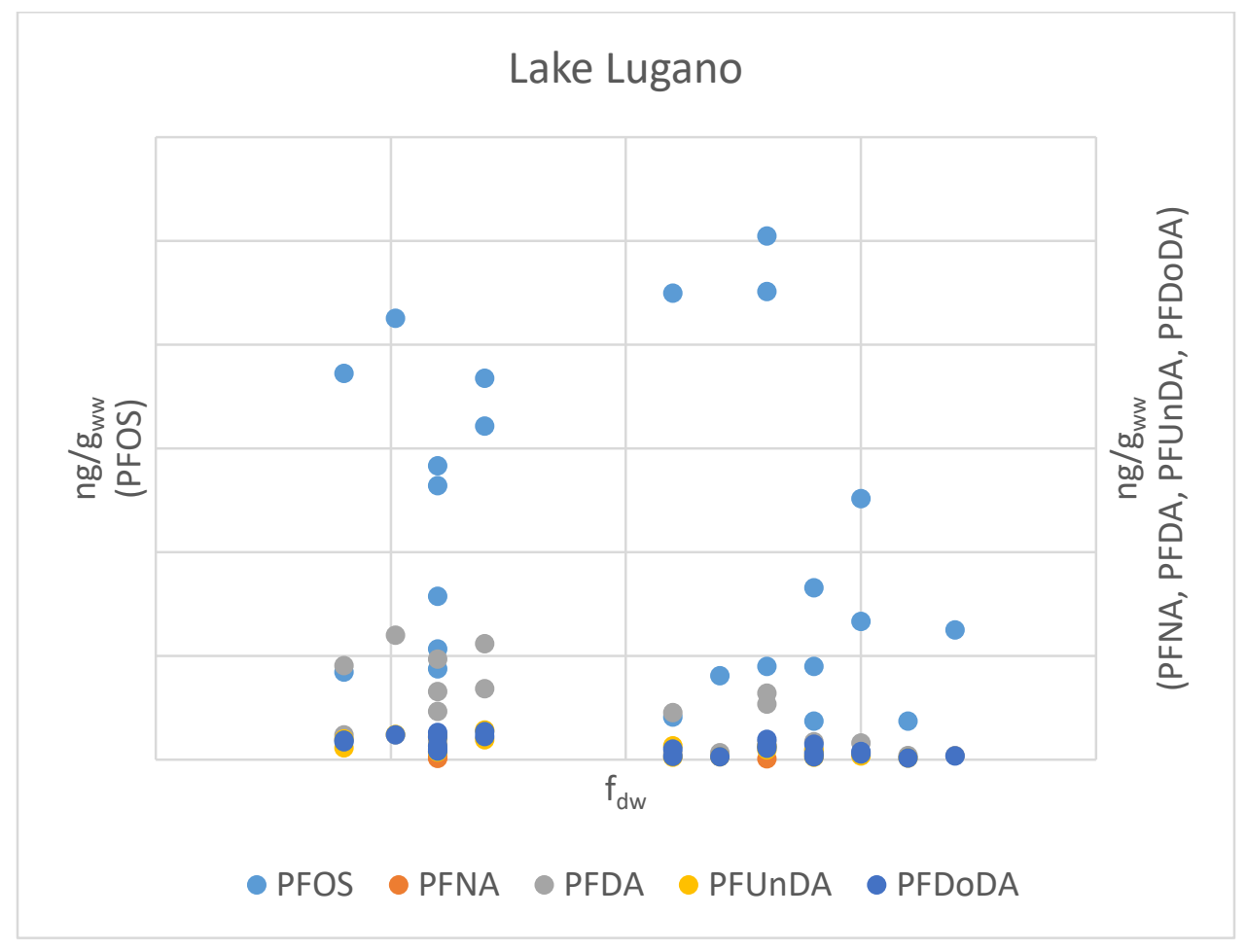

\section{Lake Lugano}

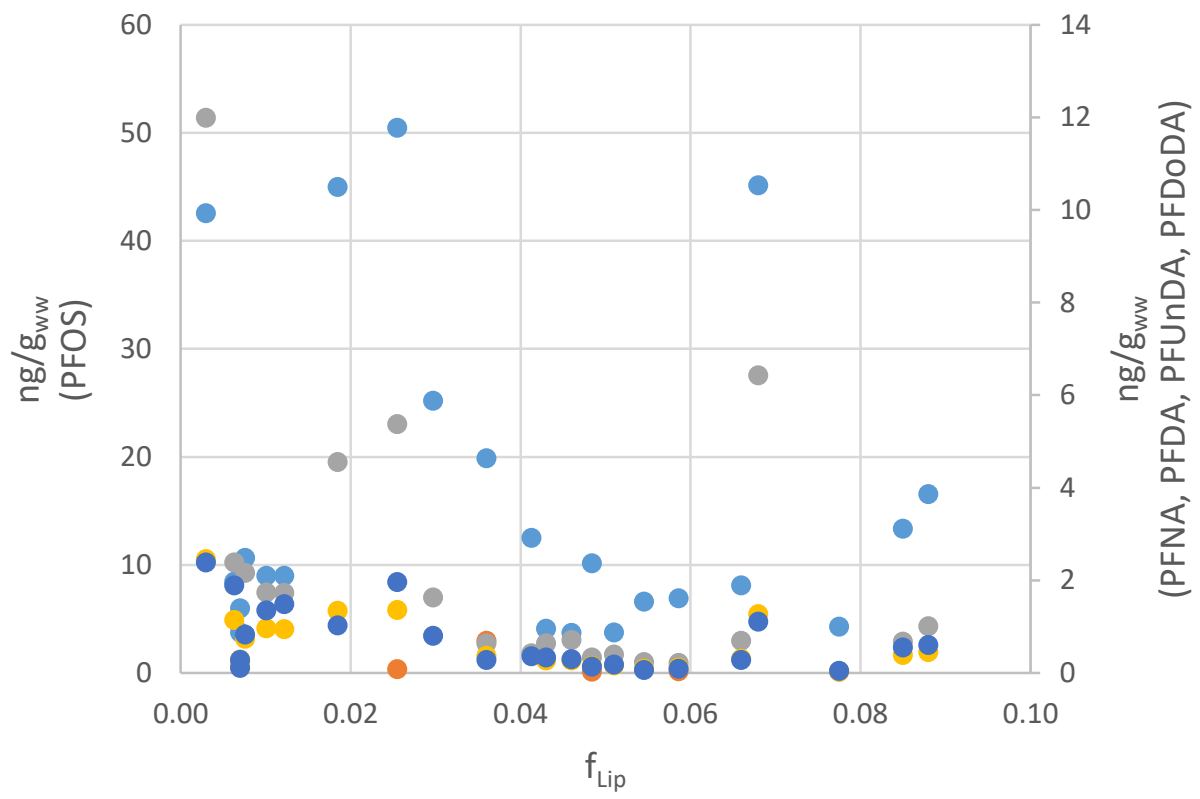

$$
\text { - PFOS - PFNA - PFDA -PFUnDA •PFDoDA }
$$

Figure S5. Plots of concentration of PFAS in fillet of Lake Lugano (ng/g $\left.\mathrm{g}_{\mathrm{ww}}\right)$ vs $a$ ) the dry 
Figure S6. Plots of medians of $\sum$ Long Chain PFCA (above) and PFOS (below) concentrations 23 vs Degurba Index (DUI)

24 Regression equations:

$25 \quad\left[\sum\right.$ LC- PFCA $]=0.043( \pm 0.005)$ DUI $-0.5( \pm 0.3)\left(\mathrm{R}^{2}=0.9413\right.$; p-value: 0.0013$)$

$26[\mathrm{PFOS}]=0.15( \pm 0.04) \mathrm{DUI}+0.3( \pm 2.0)\left(\mathrm{R}^{2}=0.7983\right.$; p-value: 0.016$)$

27 


\section{REFERENCES}

Ahrens L, Marusczak N, Rubarth J, Dommergue A, Nedjai R, Ferrari C, Ebinghaus R. 2010. Ahrens L, Marusczak N, Rubarth J, Dommergue A, Nedjai R, Ferrari C, Ebinghaus R. 2010. Distribution of perfluoroalkyl compounds and mercury in fish liver from highmountain lakes in France originating from atmospheric deposition. Environ Chem 7:422428. DOI: 10.1071/EN10025.

Ahrens L, Norstrom K, Viktor T, Cousins AP, Josefsson S. 2015. Stockholm Arlanda Airport as a source of per- and polyfluoroalkyl substances to water, sediment and fish.

Chemosphere 129:33-38. DOI: 10.1016/j.chemosphere.2014.03.136.

Akerblom S, Negm N, Wu P, Bishop K, Ahrens L. 2017. Variation and accumulation patterns of poly- and perfluoroalkyl substances (PFAS) in European perch (Perca fluviatilis) across a gradient of pristine Swedish lakes. Sci Total Environ 599-600:1685-1692. DOI: 10.1016/j.scitotenv.2017.05.032.

Berger U, Glynn A, Holmstrom KE, Berglund M, Ankarberg EH, Tornkvist A. 2009. Fish consumption as a source of human exposure to perfluorinated alkyl substances in Sweden analysis of edible fish from Lake Vattern and the Baltic Sea. Chemosphere 76:799-804. DOI: 10.1016/j.chemosphere.2009.04.044.

Bossi R, Dam M, Riget FF. 2015. Perfluorinated alkyl substances (PFAS) in terrestrial environments in Greenland and Faroe Islands. Chemosphere 129:164-169. DOI: 10.1016/j.chemosphere.2014.11.044.

Bradford MM. 1976. A rapid and sensitive method for the quantitation of microgram quantities of protein utilizing the principle of protein-dye binding. Analytical biochemistry. Analytical biochemistry 72:248-254.

Chiesa LM, Nobile M, Pasquale E, Balzaretti C, Cagnardi P, Tedesco D, Panseri S, Arioli F. 2018. Detection of perfluoroalkyl acids and sulphonates in Italian eel samples by HPLCHRMS Orbitrap. Chemosphere 193:358-364. DOI: 10.1016/j.chemosphere.2017.10.082.

Filipovic M, Woldegiorgis A, Norstrom K, Bibi M, Lindberg M, Osteras AH. 2015. Historical usage of aqueous film forming foam: a case study of the widespread distribution of perfluoroalkyl acids from a military airport to groundwater, lakes, soils and fish. Chemosphere 129:39-45. DOI: 10.1016/j.chemosphere.2014.09.005.

Hansen S, Vestergren R, Herzke D, Melhus M, Evenset A, Hanssen L, Brustad M, Sandanger TM. 2016. Exposure to per- and polyfluoroalkyl substances through the consumption of fish from lakes affected by aqueous film-forming foam emissions - A combined epidemiological and exposure modeling approach. The SAMINOR 2 Clinical Study. Environ Int 94:272-282. DOI: 10.1016/j.envint.2016.05.030.

Holzer J, Goen T, Just P, Reupert R, Rauchfuss K, Kraft M, Muller J, Wilhelm M. 2011. Perfluorinated compounds in fish and blood of anglers at Lake Mohne, Sauerland area, Germany. Environ Sci Technol 45:8046-8052. DOI: 10.1021/es104391z.

Mazzoni M, Polesello S, Rusconi M, Valsecchi S. 2016. Liquid chromatography mass spectrometry determination of perfluoroalkyl acids in environmental solid extracts after phospholipid removal and on-line turbulent flow chromatography purification. Journal of chromatography A 1453:62-70. DOI: 10.1016/j.chroma.2016.05.047.

Palacios LE, Wang T. 2005. Egg-yolk lipid fractionation and lecithin characterization. Journal of the American Oil Chemists' Society 82:571-578.

Riviere G, Sirot V, Tard A, Jean J, Marchand P, Veyrand B, Le Bizec B, Leblanc JC. 2014. Food risk assessment for perfluoroalkyl acids and brominated flame retardants in the French population: results from the second French total diet study. Sci Total Environ 491492:176-183. DOI: 10.1016/j.scitotenv.2014.01.104.

Rudel H, Muller J, Jurling H, Bartel-Steinbach M, Koschorreck J. 2011. Survey of patterns, levels, and trends of perfluorinated compounds in aquatic organisms and bird eggs from 
representative German ecosystems. Environmental science and pollution research international 18:1457-1470. DOI: 10.1007/s11356-011-0501-9.

Schuetze A, Heberer T, Effkemann S, Juergensen S. 2010. Occurrence and assessment of perfluorinated chemicals in wild fish from Northern Germany. Chemosphere 78:647-652. DOI: 10.1016/j.chemosphere.2009.12.015.

Squadrone S, Ciccotelli V, Favaro L, Scanzio T, Prearo M, Abete MC. 2014. Fish consumption as a source of human exposure to perfluorinated alkyl substances in Italy: Analysis of two edible fish from Lake Maggiore. Chemosphere 114:181-186. DOI: 10.1016/j.chemosphere.2014.04.085.

Squadrone S, Ciccotelli V, Prearo M, Favaro L, Scanzio T, Foglini C, Abete MC. 2015. Perfluorooctane sulfonate (PFOS) and perfluorooctanoic acid (PFOA): emerging contaminants of increasing concern in fish from Lake Varese, Italy. Environmental monitoring and assessment 187:438. DOI: 10.1007/s10661-015-4686-0.

Zafeiraki E, Gebbink WA, Hoogenboom R, Kotterman M, Kwadijk C, Dassenakis E, van Leeuwen SPJ. 2019. Occurrence of perfluoroalkyl substances (PFASs) in a large number of wild and farmed aquatic animals collected in the Netherlands. Chemosphere 232:415423. DOI: 10.1016/j.chemosphere.2019.05.200. 